NOTE TO USERS

This reproduction is the best copy available.

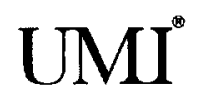





\title{
Men's Participation in Violence Prevention Efforts: A Qualitative Study of Men's Involvement in Violence Against Women Initiatives in New Brunswick
}

\author{
by
}

Miguel LeBlanc, B.S.W., R.S.W.

A Thesis submitted to the Faculty of Graduate Studies and Research

in partial fulfillment of the requirements for the degree of Master of Social Work

School of Social Work

Carleton University

Ottawa, Ontario

April 2009

(C) Copyright

2009, Miguel LeBlanc 
Library and Archives

Canada

Published Heritage

Branch

395 Wellington Street

Ottawa ON K1A ON4

Canada
Bibliothèque et

Archives Canada

Direction du

Patrimoine de l'édition

395 , rue Wellington

Ottawa ON K1A ON4

Canada
Your file Votre référence

ISBN: 978-0-494-60248-5

Our file Notre référence

ISBN: 978-0-494-60248-5
NOTICE:

The author has granted a nonexclusive license allowing Library and Archives Canada to reproduce, publish, archive, preserve, conserve, communicate to the public by telecommunication or on the Internet, loan, distribute and sell theses worldwide, for commercial or noncommercial purposes, in microform, paper, electronic and/or any other formats.

The author retains copyright ownership and moral rights in this thesis. Neither the thesis nor substantial extracts from it may be printed or otherwise reproduced without the author's permission.
AVIS:

L'auteur a accordé une licence non exclusive permettant à la Bibliothèque et Archives Canada de reproduire, publier, archiver, sauvegarder, conserver, transmettre au public par télécommunication ou par l'Internet, prêter, distribuer et vendre des thèses partout dans le monde, à des fins commerciales ou autres, sur support microforme, papier, électronique et/ou autres formats.

L'auteur conserve la propriété du droit d'auteur et des droits moraux qui protège cette thèse. $\mathrm{Ni}$ la thèse ni des extraits substantiels de celle-ci ne doivent être imprimés ou autrement reproduits sans son autorisation.
In compliance with the Canadian Privacy Act some supporting forms may have been removed from this thesis.

While these forms may be included in the document page count, their removal does not represent any loss of content from the thesis.
Conformément à la loi canadienne sur la protection de la vie privée, quelques formulaires secondaires ont été enlevés de cette thèse.

Bien que ces formulaires aient inclus dans la pagination, il n'y aura aucun contenu manquant.

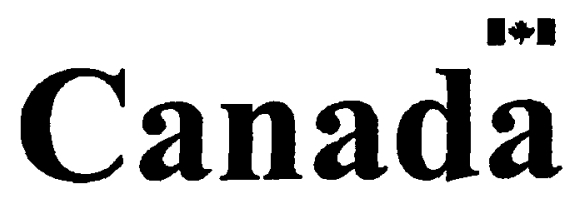




\begin{abstract}
This thesis presents a qualitative thematic analysis of seven interviews with male key informants who work in the development of male prevention efforts to eliminate violence against women by men. This study addresses gaps in the literature regarding processes directed at increasing men's participation in the struggle to eliminate violence against women by men. The theoretical foundations of this study are structural social work, feminism, hegemonic masculinity, and the Frierian's approach to community development. I argue that to authentically increase men's participation, community workers must acknowledge the well-meaning behaviours and attitudes of men and work with them to raise their consciousness of the social divisions and structures associated with violence against women by men. I provide recommendations to improve practice of community workers, including recommendations for future research to engaging men in these prevention efforts.
\end{abstract}




\section{ACKNOWLEDGEMENTS}

I would like to express my sincere gratitude to those who made the completion of this thesis a reality. First and foremost, I want to thank the men who participated in this research study. Without their participation, I would not have been able to learn from their experience and write this thesis. I am also grateful to everyone who helped in distributing my letter of information seeking research participants. Through this network of people and organizations, I was able to gain the interest of men to participate in this study.

An extended thank you goes to my supervisor, Dr. Steven Hick and to Dr. Pat Evans, my second reader, who took the time in their busy work schedule to help me through the process of finalizing my thesis.

Juggling full-time employment with my studies is not always easy. Therefore, the completion of this study would not have happened if I did not have the support from my colleagues at work and my board of directors at the New Brunswick Association of Social Workers. I want to thank Suzanne McKenna, RSW and Denise St. Laurent, my work colleagues, for their continuing encouragement and support throughout the writing phase of my thesis. I also want to acknowledge, Karine Levesque, RSW, Barbara Whitenect, RSW, Francine Prosser, RSW, Julie Ouellette, RSW, Vicki Coy, RSW, lan Rice, RSW, Merri-Lee Hanson, RSW, Hélène Caissie, RSW, Dianne Miles, RSW, Nathalie Melanson, RSW, Céline Belliveau, RSW, Monique Dubé-Michaud, RSW, Morel

Caissie, RSW, and Sandra Dimock, RSW, the Board of Directors of the New Brunswick Association of Social Workers, who provided me with incredible 
support throughout the completion of my thesis. I believe that there is a lot to learn from the example of my colleagues and my board of directors of the New Brunswick Association of Social Workers because they value the pursuit of higher education and provided me with the time needed to complete this thesis. I am forever grateful for this amazing support.

I also want to thank my family for all of their support throughout the process of completing my thesis. I am particularly indebted to my parents, Paul and Maria LeBlanc, my future mother and father in-law, Anne Macies and Rufus McKillop, and my fiancé, Laura McKillop, who provided me, not only emotional support, but the continuing intellectual feedback to make this thesis a reality. 


\section{TABLE OF CONTENTS}

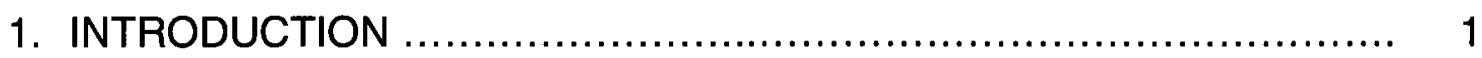

Investigator's Location ................................................. 6

Conclusion ......................................................... 9

2. THEORETICAL FRAMEWORK AND METHODOLOGY ................ 12

Structural Social Work Theory ....................................... 12

Men and Masculinity ............................................... 17

Men, Violence Against Women, and Community Development ....... 23

Classification of Key Terms ........................................ 26

Research Strategies ............................................. 28

Research Participants .......................................... 30

Data Collection ................................................. 31

Data Analysis ...................................................... 32

3. FRAMING OF MEN AND MASCULINITY ............................ 36

Participants' Framing of Masculinity ................................ $\quad 37$

Alternative Framing of Masculinity .................................... 49

Conclusion ......................................................... 52

4. MEN'S UNDERSTANDING OF VIOLENCE AGAINST WOMEN ........ 57

Perceived Versus 'Actual' Prevalence of Violence Against

Women ................................................................... 58

Power and Control Wheel ............................................... 61

Men's Personal Understanding of Violence Against Women ........... 63

Men's Socio-Political Understanding ................................. 66

Patriarchal Understanding ......................................... $\quad 70$

Conclusion ........................................................ 76

5. THE ENGAGEMENT OF MEN TO PREVENT VIOLENCE AGAINST WOMEN ............................................................. 80

Men's Role in Prevention Efforts to Eliminate Violence Against

Women .............................................................. 81

Reframing the Dialogue ........................................ 87

Consciousness-Raising and Violence Against Women by Men ........ 91

Conclusion ........................................................ 97

6. CONCLUSION ........................................................ 102

Bringing the Pieces Together ...................................... 108

References ............................................................... 112

Appendix A: Interview Guide ......................................... 119 
Appendix B: Letter of Information ...................................... 122

Appendix C: Letter of Informed Consent ............................... 125 


\section{CHAPTER ONE}

\section{INTRODUCTION}

David Henry Thoreau stated in 1849, "[t]here are thousands who are in opinion opposed to slavery and to war, who yet in effect do nothing to put an end to them ... [and] sit down with their hands in their pockets, and say that they know not what to do, and do nothing" (2004, pp.93-94). In essence, the statement holds true today, not only in reference to people's anti-war sentiments, but also on the topic of violence against women by men. Many people deplore violence against women, yet, they do not participate in its prevention. Although the majority of men, in principle, condemn physical and sexual violence against women, only a small number participate directly in the struggle for its cessation (Flood, 2001, 2002-2003). As Dankwort and Raush (2002) suggest, men's movements to end violence against women and sexism are a heartening prospect, however, they are not great in number.

The lack of participation by men in the prevention of violence against women illustrates a major challenge, which I believe must be addressed. Men need to become more involved in the prevention of violence against women. Research has demonstrated that a high number of men do not physically or sexually abuse women (DeKerseredy, Schwartz, \& Alvi, 2000; Kaufman, 1993, 2001; and Connell 1993). As Hong (2000) stated, "[i]f we are truly concerned about ending violence against women, then it is imperative that we begin working with men to prevent it" (p.277). Therefore, the question arises: what are the 
perspectives that can increase men's participation in the prevention of violence against women in New Brunswick's local communities?

Feminist and profeminist writers have argued that it is imperative to involve men in prevention initiatives to eliminate violence against women by men (hooks, 1984, 1990, and 1994; Bishop, 2002; Hagan, 1992; Flood, 2001, 2004, 2006; Johnson, 2005; and Pease, 2001), nonetheless, they are not adequate and concrete frameworks that capture the perspectives entailed in engaging men. The literature on masculinity does not sufficiently capture the processes of community building, which are necessary for increasing the participation of men in these efforts.

The involvement of men in initiatives to eliminate violence against women by men is not without controversies and dangers. For example, an increasing number of men's movements project a distorted understanding of masculinity that supports and reinforces the oppressive structures and behaviours that exploit women in our Western society. The misconceptions of masculinities can be found in men's movements such as the fathers' rights groups, the mythopoetic movement, the promise keepers, and at times, the anti-sexist movement from the 1970s and onwards (Connell, 1995, 2000; Newton, 2005; and Kimmel 2005).

One major difficulty in involving men in violence prevention efforts is that the men benefit from the historical constructs of patriarchy in our society and the subordination of women (Pease, 1999). Therefore, involving men in the struggle to end violence against women by men can be contradictory to progressive social movements since these movements have the goal of challenging and changing 
oppressive influences in our society at their roots. For example, Clatterbaugh (2000) suggests that the well-intention goal of the anti-sexist men's movement, which challenges patriarchy and sexism actually reverted to strategies that focused on self-growth and therapeutic approaches of what is considered to be a true form of masculinity, rather than challenging the structural constructs.

Although there is a gap in the literature examining effective strategies to increase men's participation to eliminate violence against women by men, some profeminist writers have been taking on the challenge to develop some preliminary approaches. Crooks, Goodall, Hughes, Jaffe, and Baker (2007) explain that there is a gap in the current literature on identifying a detailed framework to engage men in anti-violence initiatives. Throughout their research Crooks et al. (2007) argue this lack of a framework can have negative impacts on how we develop in-depth prevention efforts to end violence against women involving men. The authors suggest that men who are involved in prevention efforts must identify their goals with greater specificity (Crooks et al., 2007).

Crooks et al. (2007) suggests three main methods for engaging men. The first method is to build a roadmap for men that provides clear direction and goal. For example, is the goal to engage men who were violent in the past in prevention efforts, or is the goal to increase the sense of ownership among nonviolent men by developing processes in which they will speak out among their male peers when a sexist joke is told. The second component must be to develop new notions of masculinities and identify steps to reach such new dialogues. Unfortunately, most prevention efforts do not include discussions on 
masculinity (Katz, 1995; Connel, 1995; and Kimmel, 2005). In reality, most discussions pertaining to masculinity can only be found when directly working with violent men. Profeminist writers (Connel, 1995; and Katz, 1995) illustrate the major implications of hegemonic masculinities on men as contributing to unrealistic expectations and behaviours in our societies. Therefore, the concept of masculinity must be in the forefront of prevention efforts in our communities. The third component suggested by Crooks et al. is that profeminist men and women who identify themselves as feminist, must acknowledge men's 'wellmeaning' behaviours as a launching pad for change and engagement. Therefore, prevention efforts striving to engage men, must take initiatives that will acknowledge the well meaning ideas and efforts of men, who may not have an analysis that fully follows the profeminist and feminist ideals regarding violence against women. This acknowledgement provides the opportunity for raising the consciousness of men about their values and beliefs regarding profeminism and general feminist movements. Raising men's level of consciousness has the potential of changing their pre-conceived understanding of feminisms, which may move these individuals towards a greater acceptance of profeminist approaches and understandings for ending violence against women in our societies. Pease suggests, "that men can change in the direction of feminism. Men have choices as to whether they accept patriarchy or work collectively against it. Before men can organize collectively, though, they must transform their subjectivities and practices" $(2001$, p.3). Therefore, it is imperative that profeminist men and feminist women become more open minded and acknowledge the well meaning 
men by providing space for these potential allies to grow in their feminist understandings and analyses.

DeKeseredy, Schwartz, and Alvi (2000) state, "the more men who become profeminist the more likely that changes will occur" (p.927). One method to increase the numbers of profeminist men is through education programs, which according to Flood:

Can significantly reduce their support for and participation in sexual violence. Violence prevention programs can lessen men's adherence to the attitudes and values associate with sexual violence, increase men's emotional and moral compassion, encourage men to intervene in the behavior of other men, and reduce men's future violence. (2006, p.10).

Flood suggests there is a need to assess violence prevention efforts and further explains, "it is troubling to note that some interventions do little to create lasting change or even make men's attitudes worse. Nevertheless, existing evaluations do show that many programs produce short-term positive change and some produce long-term changes in attitudes and behaviours" (2006, p.10). The importance of public education to raise men's consciousness is important, however, as Kaufman (2001) explains, to be sustainable on a long-term basis, there needs to be processes developed that authentically engage men's participation in prevention efforts of violence against women in our communities. In addition, sustainability on a long-term basis needs to include change to the structures of society that support and reinforce violence against women by men.

DeKeseredy et al. (2000) suggest that one strategy that is imperative to prevent violence against women is to develop processes that will increase the knowledge of men about anti-sexism. Examples that will create a deeper 
understanding of anti-sexist men can range, according to Dekeseredy et al. (2000), through focus groups, to understand the reasons men do not join antiviolence initiatives and to adjust the prevention strategies appropriately. Other ideas suggested by Dekeseredy et al. (2000) are to create a network of allies to provide support, eliminate the potential of re-inventing the wheel, protesting and letter writing or other methods to disseminate information in the public forum. According to Dekeseredy et al., "profeminist men should take every opportunity to disseminate their views to the mass media" (2000, p.929). Dekeseredy et al. (2000) by quoting Renzetti, explains that this results in anti-sexist men being "seen and heard, not after the fact, but proactively" (1999, pp.929-930).

However, the literature on engaging men in the struggle to eliminate violence against women by men does not adequately address the processes that are involved for the development of engagement strategies to end violence by men towards women. Therefore, this thesis will examine these processes by interviewing men who are involved in this issue within New Brunswick.

An important aspect in qualitative research deriving from the feminist tradition is identifying the location of the investigator who is doing the study. To this effect, the following section will discuss my location within the field of inquiry as the researcher, by identifying my background and interest in regards to this investigation.

\section{Investigator's Location}

Throughout my involvement with the issue of working to eliminate violence against women by men, I gained an increased sense of appreciation for feminist 
writings. An important component of feminisms qualitative research is acknowledging the researcher's location (Harding, 1990; and Reinharz, 1992). As Reinharz states:

I, for one, feel most satisfied by a stance that acknowledges the researcher's position right up front, and that does not think of objectivity and subjectivity as warring with each other, but rather as serving each other. I have feminist distrust for research reports that include no statement about the researcher's experience. Reading such reports, I feel that the researcher is hiding from me or does not know how important personal experience is. Such reports seem woefully incomplete and even dishonest (1992, p.263).

I believe it is important to state my location as a researcher within this field of inquiry, therefore, I provide a brief overview of my experience within this field of inquiry.

My interest in the topic of violence against women developed during my undergraduate studies while completing my Bachelor of Social Work. I was involved in the development of Menswork/Voix d'hommes, a provincial grassroots network of men who mobilized with the goal to begin a dialogue on how men could work in concert with the women's movement as allies in the struggle to end violence against women in the province of New Brunswick. The mandate of Menswork/Voix d'hommes was to develop initiatives focusing on preventing violence against women committed by men. Furthermore, Menswork/Voix d'hommes' goal was to begin processes of engagement at the grassroots level and to take action in the struggle to end violence against women. Menswork/Voix d'hommes, furthermore, participated in an initiative of 
the Fredericton Sexual Assault Crisis Centre, entitled Mensproject. The coordinators at the Fredericton Sexual Assault Crisis Centre approached me to be involved as a consultant.

The Mensproject is an initiative that aims to increase the participation of men of all ages regarding the struggle to end sexual violence in New Brunswick. Through my discussions with men who were involved with this project I began to develop a greater sense of the barriers to increasing the participation of men to end violence against women in our communities. For example, numerous contradictions and tensions occurred in my discussions with the other male stakeholders. The discussions highlighted various understandings of the root causes of violence against women, of feminist approaches and theories, and different approaches to male engagement on these issues. In addition, my personal discussions with men of all ages in my community exposed a similar diversity of ideas. For the most part, men agreed that violence is unacceptable. However, when talking with men about the root causes of violence against women, or how to increase participation of men to end violence against women, there were conflicting responses. Many men held a distorted understanding of feminisms, such as feminists hate men or are male bashing. Other men believed that since they were not committing violent acts towards women, which were usually associated with physical or sexual acts (e.g., hitting a woman or sexually assaulting a woman), they rationalized that there is no need for them to be involved in its prevention. Reflecting on these experiences, I began to wonder 
what I was missing in my understanding on how to increase men's participation in community movements or initiatives to end violence against women.

\section{Conclusion}

This chapter provides an overview of the location of this thesis. Drawing from feminist writings, I identify my location as the researcher within this field of inquiry. The principal research question is to gain an understanding of "what are the perspectives that can increase men's participation in the prevention of violence against women in New Brunswick's local communities?"

My thesis consists of five other chapters. Chapter two, Theoretical Framework and Methodology, discusses the methodology used for this qualitative study, which identifies the different theoretical framework that inform this thesis. To complement this section, I incorporated an in-depth literature review in which is interwoven throughout the thesis. This approach provided greater possibilities in providing a critical analysis of the participants' dialogue associated with the focus of this study. This chapter situates the processes that I used to find the participants, the process of data collection, and how I undertook a thematic analysis for identifying the themes from the participants. The methodology chapter also highlights the limitations of the study and shows that because of the nature of the study, the findings are not generalizable to the general population. Rather, the focus of the study is to gain an understanding of how the men understand the processes necessary to the development of initiatives to increase the participation of men in the struggle to end violence against women. Furthermore, I provide a critical analysis of the themes that men 
believe are necessary for increasing the participation of other men in their efforts to prevent violence against women by men in their communities.

Chapter three is an examination of themes that I group under the title, Framing of Men and Masculinity. The research participants identify the importance of the social construction of men and masculinity in our Western society. This chapter also examines the commonalities and differences of how the men describe the notion of men and masculinity. I suggest that the majority of the men's understanding of men and masculinity, links to the concept of hegemonic masculinity, however, the majority of the men simply identify the symptoms of hegemonic masculinity and do not identify the root causes of this construct. I also discuss how one man argues that the framing of men and masculinity derives from the ideas of the mythopoetic men's movement.

Chapter four highlights that all of the research participants believe it is important to have an understanding of violence against women if we want to develop engagement strategies for men to eliminate constructs of violence in our society. Therefore, this chapter, Men's Understanding of Violence Against Women, is the grouping of themes on how men define and understand violence against women in their communities. As we will see, only three of seven men go further than the behavioural symptoms of violence against women by bridging the connections between the personal spheres and the structural context associated with violence against women

Chapter five, The Engagement of Men To Prevent Violence Against Women, is an examination of the groupings of themes regarding the processes 
of developing engagement strategies that involves men in the prevention of violence against women. This chapter illustrates that the majority of men do not provide processes that have the potential of challenging the socio-political context associated with violence against women by men. Rather, the majority of the research participants provide ideas and themes that address the symptoms without adequately challenging the structural constructs of violence against women by men. Nevertheless, the chapter suggests that community workers must acknowledge the 'good will' of these men and work with them to develop initiatives that will increase the men's critical consciousness in regards to violence against women by men.

The final chapter, the Conclusion, brings the themes of the three chapters together and illustrates the interconnectedness among them by providing an analysis, by showing the 'big picture' of the findings from this study. I also discuss areas that I believe are in need of further research. 


\section{CHAPTER TWO}

\section{THEORETICAL FRAMEWORK AND METHODOLOGY}

This chapter describes the methodology and the theoretical framework that underlines my research. The theoretical foundations of this qualitative study are structural social work, feminism, hegemonic masculinity and the Frierian's approach to community development. The chapter begins with an examination of the theoretical frameworks of structural social work and follows with a discussion of feminism, men and masculinity, specifically, hegemonic masculinity. The chapter follows with the theory underpinning men and violence against women interwoven with community development theory, specifically the writings by Paulo Freire. This chapter also defines and illustrates the importance of several terms that I used within this inquiry, the research strategies associated with the methodologies, how I recruited the participants, and the criteria for selection for this study. I further identify the steps I undertook to ensure that all participants comprehended the purpose of the research and how I gained their informed consent to participate in this study. This chapter discusses the methods I used in the collection of the data and ends with a discussion on how I undertook a thematic analysis of the data for this study.

\section{Structural Social Work Theory}

In the 1970s, Maurice Moreau, along with his colleagues at Carleton University developed the structural social work approach. Moreau explains:

The structural approach to social work practice is, in broad terms, not new, in that it incorporates tasks that social workers have historically undertaken as part of 
professional commitment and responsibility. What it does do that is new, however, is to systematically assure a fuller conceptualization of social problems and reformulation of objectives (1979, p.78).

Moreau (1979) and his colleagues were challenging the dominant and traditional practices and understandings of social work that focused primarily on a biomedical and disease model of analysis and intervention. In other words, Moreau clarifies structural social work as challenging the prevalent social work practice which focuses on "the person more than the situation" $(1979$, p.78) resulting in clients being in positions of passivity and/or dependency, rather than working towards empowerment with clients by linking their personal situation within the structural context.

A major assumption within a structural social work approach is that it attempts to bridge the personal life experience of individuals with the sociopolitical context within society. Lecomte explains that the bridging "of both the personal and the socio-political dimensions is crucial in any attempt at social change" (1990, p.48). Mullaly (1997) and Lundy (2004) explain that structural social work views the problems of individuals, family, community, or society as deriving primarily from the influences of institutions or structures upon a subject. As Mullaly states:

The term 'structural' in structural social work is both descriptive and prescriptive. It is descriptive in the sense that the major source of social problems is described as being located in the way our society is structured. It is prescriptive in the sense that because social problems are rooted in our social structures, then the structures must be changed and not the individual, the family, or the subculture adversely affected by social problems (1997, p.134). 
Furthermore, Lundy (2004) explains:

A structural approach to social work attempts to bridge the duality of the personal and the social, the individual and the community, and offers social workers an understanding of diverse populations in the context of social structures and social processes that generally support and reproduce social problems (p. 57).

Therefore, a structural social work approach understands the interconnectedness of the personal and socio-political spheres, and the social workers' role is to work to eliminate the oppressive structures that are negatively affecting people.

Implicit in structural social work is the idea that there is no hierarchy of oppression, rather, the various forms of oppression are interrelated and support each other to oppress people through the societal structures of society (Carniol, 1995; and Mullaly, 1997, 2007). Therefore, the theoretical framework of structural social work views personal problems as being influenced and supported by the oppressive structures that intersect class, gender, race, sexuality, language, ability and other forms of oppression. Consequently, "a function of the profession of social work should be on eliminating these disparities. Structural theory argues that these arrangements serve those in power, allowing them to maintain their power and privilege at the expenses of others" (Weinberg, 2008, p.1).

Nevertheless, these hierarchical constructs, for example, capitalism or patriarchy, do not suggest that individuals never take responsibility for their actions, rather, structural social workers understand that change at both the individual and societal spheres is necessary (Lundy, 2004; and Mullaly, 1997). Therefore, the 
goal of structural social work is working for social change at the personal sphere and the socio-political sphere and is based on the ideals of social justice.

However, there are limitations to structural social work theory. The limitations to structural social work theory are primarily that it is informed from modernist assumptions without adequate involvement of post-modern theory. Mullaly (2007) attempts to address these limitations by developing a new form of structural social work that incorporates the strengths of both modernist and postmodernist views. Mullaly (2007) explains:

Structural social work does not perceive these two perspectives on critical theory [i.e., modernism and post-modernisms] to be completely dichotomous or polarized. Instead, it views each as having strengths and limitations that the other does not and seeks to use the strengths of each as a corrective for some of the limitations and contradictions of the other (p. 223).

Mullaly (2007) believes "the contribution of critical postmodernism to a structural analysis is to help us recognize that although oppression and exploitation may be universal phenomena, they will be experienced differently by different people living in different places in different contexts" (p. 224). Therefore, Mullaly (2007) illustrates the importance of incorporating both modernist and post-modernist understandings into the theoretical framework of structural social work. Consequently, the influence by post-modernist theorists provides opportunities for supplementing and strengthening the gaps within the modernist traditions, such as structural theories. The concept of power is a focus within postmodernist writings and strengthens some of the gaps within modernist assumptions of structural social work. 
Foucault's writings (1980 and 1984) illustrate the importance of understanding and deconstructing all forms of power. Furthermore, Mullaly (2002) explains that Foucault's writings "argued that power is always faced with resistance, that every exercise of power is contested, and that resistance itself is an act of countervailing power" (p.21). Such concepts, according to the author, provide anti-oppressive social work practices with greater possibilities to create social change (Mullaly, 2002). Writing from a black feminist perspective, hooks (1990) states:

The overall impact of postmodernism is that many other groups now share with black folks a sense of deep alienation, despair, uncertainty, loss of a sense of grounding even if it is not informed by shared circumstance. Radical postmodernism calls attention to those shared sensibilities which cross the boundaries of class, gender, race, etc., that could be fertile ground for the construction of empathy-ties that would promote recognition of common commitments, and serve as a base for solidarity and coalition (1990, p.27).

Therefore, hooks recognizes the importance of incorporating elements of postmodernism in one's analysis. This results in an opportunity to develop a progressive movement grounded in ideas of social justice and social change because postmodern theory recognizes power differences within all structures, groups, and people in society. As Mullaly (2002) discusses, postmodern writings facilitate in bridging the gaps between the weaknesses (e.g., dichotomist thinking) and the ideas (e.g., social justice and equality) of modernist theories. My research explores men's understanding of the structural context of violence against women by men and highlights the different experiences and forms of resistances that my research participants articulate throughout the interviews. 
Various elements of men's experiences and resistance relate to how men view their masculine identity in the Western society.

\section{Men and Masculinity}

The complexities of gender became more evident throughout the years with an increase of research by feminist writers. By examining the concept of gender, feminist researchers such as Butler (1990) and Connell (2002) demonstrate that the feminine and masculine are not a simple dichotomy. Rather, the differences between the feminine and masculine are socially constructed and as such, must be examined within the context of people's constructs when they name their differences between genders. Connell summarizes this concept succinctly by stating, "gender is a way in which social practice is ordered" (1995, p.71). This idea, according to Judith Gardiner, is the most important contribution to feminist literature in the $20^{\text {th }}$ century. Gardiner states:

The concept of gender as a social construction; that is, the idea that masculinity and femininity are loosely defined, historically variable, and interrelated social ascriptions to persons with certain kinds of bodies - not the natural, necessary or ideal of characteristics of people with similar genitals. (2005, p.35).

In other words, gender is not a biological predisposition of sex (i.e., body); rather, gender is a social construct that is defined by individuals within our society and changes throughout history. Therefore, different perspectives have been argued to explain how people view masculinity within society. 
Rocco Capraro (1994) suggests the following three general groupings in understanding and identifying masculinities within society: the conservative perspective, the mythopoetic perspective, and the feminist perspective. The conservative perspective illustrates a traditional view of men in our society, such as men are inherently more intelligent, strong, and dominant compared to women. The mythopoetic perspective views masculinity in the context of men suffering loss of identity and struggling between the traditional man and the new age soft man. The feminist perspective views men as a group that has power over women which reinforces sexism.

Capraro (1994) explains that the conservative perspective exemplifies the traditional roles of men in our society, and as such, the ideology of the male sex role is considered to be closely aligned with the conservative ideology regarding both the masculine and feminine. Men who hold these patriarchal beliefs, as Connell states are "affirming a conservative sexual ideology underpinned by conventional divisions of labour and by the institution of marriage" (1995, p.178). In other words, proponents of the conservative ideology believe in a dichotomous understanding of the masculine and feminine as each having an inherent sex role. Connell (1995) explains the late nineteenth-century resistance to women's emancipation derived from the male sex role that propagated beliefs of innate sex differences between the feminine and masculine. Consequently, the supporters of these ideals argue the supremacy of the masculine over the feminine; in other words, the masculine as more powerful than the feminine. One argument of these supporters is that the university is exclusively a sphere for 
men because women have inherent weaknesses (i.e., their feminine mind). This resulted in the belief that women are not able to handle the rigorous life of academia (Connell, 1995). Arguments such as these reinforce the idea that men are inherently dominant and biologically stronger, and as a result, have an inherent instinct to be violent. As such, an argument to explain violence against women by men is that the male perpetrators lack a notion of civility (Hong 1999). Therefore, Hong (1999) explains that prevention efforts informed by this conservative perspective believe that society must develop processes that will result in increasing the civility of men towards women within our society to mitigate violence against women.

The second perspective described by Capraro (1994) is the mythopoetic perspective. According to Capraro (1994), to understand the key tenets of the mythopoetic phenomenon, we must examine the arguments of Robert Bly, one of its key founders, who believes that there are two unacceptable concepts of masculinity. The first concept is the historical portrayals and values associated with the traditional male figure who is the father and provider of the family structure (Capraro, 1994). The second depiction of men is the ideal of a soft male. According to Bly, the soft men are men who are in tune with their feminine characteristics through the influences of the feminism movements (Capraro, 1994). Consequently, the conflict between the two ideals creates a loss of male identify within our society that creates processes of grief and hurt.

Men who attempt to reclaim their loss of self due to these conflicts, end up displaying unhealthy behaviours, such as being violent towards women. The 
cause for these unhealthy behaviours is that men are trying to reclaim their masculine identity and their power. As such, Connell (1995) explains that men must reject these two models and turn inwards to recapture their primordial emotions as true men. This process is called the Wildman. According to Bly, men are not born as violent individuals, rather, Wildmen are living from strength and when they are detached from this concept, men are weak and unsure of themselves and will react by violent means (Thorne-Finch, 1995). Consequently, men must reconnect with their inner sense and participate in gatherings and rituals which allows men to recapture their primordial masculine emotions (Connell, 1995; Thorne-Finch, 1995).

The third perspective articulated by Capraro (1994) is the feminist perspective of masculinity. Jaggar (1983) explains that feminist perspectives have a rich history, and "in a sense, feminism has always existed. Certainly, as long as women have been subordinated, they have resisted that subordination" (p.3). Therefore, feminists' scholarships are diverse and range across different theoretical frameworks and paradigms (Jaggar, 1983). Nonetheless, Payne states, "feminist perspectives on social work focus on explaining and responding to the oppressed position of women in most societies" (2005, p.251). For this study, socialist feminism is the theoretical framework which:

Emphasizes women's oppression as part of structured inequality within a class-based social system. Because women are an important part of reproducing the workforce for the benefit of capitalism by carrying out domestic tasks and child care .... Women's oppression interacts with other forms of oppression (such as race, disability). Oppressive social relations should be analysed and understood, 
so that diverse interests can be met in various different ways (Payne, 2005, p. 253).

Feminist perspectives also incorporate an understanding that men, as a group, have power over women. Seidler (1999) provides an example of male power found within the traditional family structure. He states:

Traditionally men had been the sources of authority within the family, while women and children were defined the reason they supposedly lacked. It was part of a man's duty and part of his own responsibility to his own manhood to expect his voice to be respected 'as law' within the family. There could only be one source of authority and this had to be him" (Seidler, 1999, pp.187-188).

Therefore, feminism perspectives draw attention to the unequal power distributions between men and women in society. This unequal distribution of power and gender divisions is influenced by the concepts of patriarchy. Amanda Goldrick-Jones explains that:

In its broadest sense, patriarchy encompasses a vast network of attitudes, behaviours, and institutional structures that enable men to exercise power and claim privileges to 'all men' at the expenses of 'all women'. The offspring of patriarchy - capitalism, racism, heterosexism, and the equation of masculinity with physical power and strength (2002, p.184).

Oppressive gender divisions, such as paid and unpaid work, reinforces the structural elements within society that devalues women's contributions in our capitalist and patriarchal society. Women's work is continually devalued in a patriarchal and capitalist society. For example, women are continually being paid less than men for doing the same work. The majority of women are also in professions that are viewed as 'feminine work', such as social work, which 
society does not compensate adequately because of the capitalist and patriarchal structures of society. An example of unpaid work that is generally associated with women is housework and care giving. This unpaid labour is not valued as contributing to our capitalist society, but is a taken for granted aspect of paid and unpaid work, and reinforces the oppression of women in our society. Therefore, these masculine constructions perpetrate the personal and sociopolitical spheres of violence against women by men.

Hong (1999) explains the phenomenon of patriarchy as reinforcing the concept of sexisms. Hong states, "this sexism is the foundation of gender differences, teaching men to devalue women or anything feminine, and labeling women as 'deviant' in order to give men control over women through sexist practices and violence" $(1999, \mathrm{p} .85)$. Therefore, this conceptualization suggests that patriarchy is one of the roots of men's understanding and formulation of masculinity.

Although the idea of power over is an important concept to understand in relation to masculinity, it is imperative to recognize the complexities involved in this construct. The ideas of 'feminism not only challenged men's power in relation to women but it also threatened men's relationships to their masculinities" (Seidler, 1999, p. 186). Furthermore, hooks explains:

Patriarchal masculinity teaches men that their sense of self and identity, their reason for being, resides in their capacity to dominate others. To change this males must critique and challenge male domination of the planet, of less powerful men, of women, and children. But they must also have a clear vision of what feminist masculinity looks like (2000, p.70). 
Therefore, profeminist writers examined the relationship between men and masculinities and developed feminist analyses to explain this phenomenon. Connell (1995), Kaufman (1993), Kimmell (2005) and Hearn (2001) explain the relationship between men and masculinities in more details. For example, Connell (1995) provides the argument that not all men necessarily benefit from masculinity and most notions of masculinity are not real and reachable. In other words, men are trying to reach a false and unattainable identity. There are several different key terms identifying this masculine illusion. Connell (1995) names this phenomenon hegemonic masculinity; Kaufman (1993) uses the concept of hypermasculinity. Regardless, all of these key terms postulate a similar argument in which men are attempting to adjust their behaviours to conform to unattainable social constructions. One classic example explaining these social constructions is the idea that a 'real man' must strive to become a Rambo, John Wayne, another figment of the imagination, or influential Hollywood creation, none of which are real human beings. Nonetheless, men in our society do adopt these illusions of Rambo, John Wayne, and other fictional creations into their values, beliefs, perceptions, and behaviours.

\section{Men, Violence Against Women, and Community Development}

The involvement of men in eliminating violence against women by men is viewed as an important element for transforming society towards social justice (Hagan, 1992; and Flood, 2001). hooks (1984) reminds us that:

All men support and perpetuate sexism and sexist oppression in one form or another. It is crucial that feminist activists not get bogged down in intensifying our awareness of this fact to the extent that we do not 
stress the more unemphasized point which is that men can lead life affirming, meaningful lives without exploiting and oppressing women. Like women, men have been socialized to passively accept sexist ideology (p.72).

Recognizing that men can lead lives that are not exploiting and oppressing women provides the opportunity to develop strategies to enable men to become involved in anti-violence work. However, most strategies regarding violence against women are based on intervention strategies that focus on the perpetration of violence by men, and not on initiatives that deal with community prevention approaches, which is an important approach to eliminating violence against women by men (Wolfe \& Jaffee, 1999).

Flood (2006), Katz (1995), and Kaufman, (2001) suggest that incorporating community initiatives that involve men in the struggle to end violence against women is vital. As Pease states, "the struggle to overthrow patriarchy must be a movement of both men and women, in which men must acknowledge the injustice of their historical privilege as men" (2002, p.167). Men who become allies must recognize that the process will not be easy. (Bishop, 2002). However, this process is vital for men who want to become allies in the struggle to eliminate violence against women. Carniol (2005) suggests that men must recognize that they cannot take a leadership role because of the inherent oppressive elements of patriarchy in our society. Therefore, men will need to work in concert with the women's movement as allies by challenging the sociopolitical dimensions that oppress women, such as patriarchy. This study will examine the processes that the male research participants believe are important 
for increasing the participation of men in violence against women prevention initiatives.

Flood (2006) also argues that men must develop community development initiatives and collective efforts, particularly in the area of prevention. An example of a collective effort to prevent violence against women is Katz's Mentors in Violence Prevention (MVP), which works with male university athletes to become mentors and leaders in the prevention of violence against women (2005). There are different community models (Payne, 2005), but an important concept in community development that focuses on social change for social justice entails the concepts of consciousness-raising.

The writings of Paulo Freire are informing this thesis with his revolutionary pedagogical model of adult education and its relationship with community development. Freire's model of adult education involves a process that he coins 'praxis'. The concept of praxis is that every action must be informed with reflection, and that this in turn is a cyclical process (Freire, 2000). Freire argues that this model provides the opportunity for the oppressed to increase the level of critical consciousness of their own life experiences (2000). Consequently, hooks (1994) believes that the process of critical consciousness provides the prospect for the oppressed to develop revolutionary social change. Although the Freirian model for social change has been criticized as male centered and patriarchal, hooks (1994) argues that this model for social change should not be dismissed. Rather, hooks (1994) explains that incorporating feminist analysis in Freire's framework provides the opportunity to expand on the model and address the 
weaknesses, such as challenging and changing the ideas that stem from a patriarchal understanding.

The concept of consciousness-raising as described by Ife and Tesoriero (2006) is an important aspect for increasing the participation of people who live in a community. The assumptions of consciousness-raising derives from the idea of bringing people together to share their experiences and views on issues about common problems and join together to take pro-active actions to change the situation (Naples, 1998, hooks, 1984 \& 1994, Adamson, Brisking, \& McPhail, 1988, Ife \& Tessoriero, 2006). This study argues that consciousness-raising methodologies are a vital aspect to engaging men in the issues of violence against women.

\section{Classifications of Key Terms}

For the purpose of this thesis, I am stating the definitions or the major objectives behind the following terms: participation; ally; and violence. The important objectives of participation is:

The aim being for everyone in the community to be actively involved in community processes and activities, and to recreate community and personal futures. Participation is therefore an important part of empowerment and consciousness-raising. The more people who are active participants and the more fully they participate, the more ideals of community ownership and inclusive processes will be realized (Ife \& Tesoriero, 2006, p.145).

Furthermore, Ife and Tesoriero (2006) explain that there are five conditions that support participation. The first condition is people must believe that the issue and activity is important. The second, is people must believe they can make a 
difference. Third, is all forms of participation must be recognized and appreciated. The fourth is citizens must believe that they are permitted to participate and supported through their participation, and the final condition is that the arrangements and procedures must not create distances in people to participate (Ife \& Tesoriero, 2006).

The definition of ally is provided by Bishop (2002) who states an ally is "a member of an oppressor group who works to end a form of oppression which gives her or him privilege. For example, a white person who works to end racism or a man who works to end sexism" (p.152). Therefore, for the purpose of this thesis, allies are men who are working with other men, women's groups, and/or organizations who are pro-actively struggling to end violence against women by men in communities.

The term violence for this thesis follow the definition by Bulhan (1985) who states, "violence is any relation, process, or condition by which an individual or a group violates the physical, social, and/or psychological integrity of another person or group" (quoted in Mullaly, 2007, p.271). Mullaly (2007) further clarifies that the definition by Bulhan connects with structural violence, and adds that Bulhan (1985) explains "structural violence involves more than the violation of fairness and justice ... [it] leads to hidden but lethal inequities, which can lead to the death of those who lack power or influence in society" (quoted in Mullaly, 2007, p.271). 


\section{Research Strategies}

The methodology for this thesis involves a qualitative approach to data collection that includes in-depth semi-structured key informants' interviews with seven men who are involved in the field of violence against women perpetrated by men in New Brunswick. According to Hornosty and Doherty, "qualitative research methods are the most appropriate means of exploring people's views of their experience and reality" (2003, p.42). My research follows an exploratory design as described by Marlow (2005) which provides the opportunity to gather information for understanding the processes that my research participants believe are needed for increasing men's participation towards the prevention of violence against women. Furthermore, the in-depth semi-structured interviews provide the opportunity to go in-depth with the informants to answer the research questions for this study. Another strength of this framework is that it captures the voices of people who are submerged within the field of inquiry. The interview format for this thesis is semi-structured. I developed a set of questions as my interview guide (Appendix A), which acted as a baseline for my interviews. Marlow (2005) explains a semi-structured interview provides the researcher with the freedom to probe areas of interest during the interview that may enrich the data collected. The length of my interviews with the male participants ranged between one hour and thirty minutes to two hours.

The process of key informant interviews provides the opportunity for the participants to explain their own perspectives on violence against women in society. Marlow (2005) explains the process of key informant interviews as 
relying "on people in the community [who are] identified as experts in the field of interest" (p.145) to contribute in the research. The interviewees provided their own understanding of violence against women perpetrated by men and how the social construction of masculinity supports the phenomenon of violence in society. The interview process allowed the participants to provide their own expertise on how we can construct processes that will facilitate and increase men's participation in eliminating violence against women. The in-depth key informant interviews provided me with the opportunity to examine the men's constructions of violence against women and offered a framework that enabled me to conduct a structural analysis of the data.

During the interviews with the research participants, I asked the men the questions from my interview guide. The purpose of the interview guide was to facilitate the process of answering the principal research question for this study, which is "what are the perspectives that can increase men's participation in the prevention of violence against women in New Brunswick's local communities?" In addition, I provided all of the participating men with the opportunity to expand, clarify, and add to their statements throughout the interviews.

Since the selection of research participants was not done by using a random sample and only includes men living in New Brunswick, I am not able to generalize the findings to the whole population. Furthermore, this study is not representative of the population in question because the sample is too small. Nonetheless, this data offers me an in-depth understanding of the key informants' beliefs on how to engage men in prevention efforts of violence 
against women and the processes that are needed to increase men's participation in the elimination of violence against women. Consistent with the goal of a qualitative research methodology, I focused on the quality and depth of the information rather than the quantity of information. Hornorsty and Doherty state, "unlike quantitative studies that are concerned more with issues of frequency and distribution, qualitative research is rooted in the perspective of participants and their subjective meanings" (2003, p.42).

\section{Research Participants}

I conducted key informant interviews with seven men who are involved in the field of violence against women perpetrated by men in New Brunswick. There were two criteria for the eligibility of the research participants to participate in this research. The first criterion was that the male participants must be eighteen or older, the second was that the participants must be involved in the prevention of violence against women in their communities. The participants' involvement regarding the issues of violence against women by men included both paid and volunteer work. Their responsibilities ranged from men working as a counselor with abusive men to working in communities and/or in the province for developing prevention or intervention strategies. The experience of the participants ranged between over thirty years of involvement to a couple of years. The participants' level of education ranged from some undergraduate study to participants with a PhD. Consequently, the men in this study have an understanding of violence against women by men and they provide their views and perspectives on what 
they believe are important methods to increase men's participation in the prevention of violence against women.

\section{Data Collection}

The recruitment processes for this research involved disseminating the letter of information (Appendix B) through email distribution from interested stakeholders, such as community-based organizations and governmental departments, and other informal email networks from individual members of the community. The letter of information invited interested men to participate in this study and I received interest from seven men that lived across New Brunswick. Through the dissemination phase, I was able to coordinate and schedule interviews with research participants from across the province. Furthermore, the recruitment of participants also occurred through a snowballing effect because the men who participated in this research were provided the opportunity, if they chose, to email or forward the letter of information to other potentially interested men. I scheduled the interviews with the research participant at their convenience. I traveled across New Brunswick to their specific localities to complete the interviews. The interviews took place at the participants chosen location. I interviewed one participant at his home, two at their workplace, two on different University campuses, and two at non-profit organizations meeting rooms.

The investigation was of minimum risk to the research participants. In addition to the letter of information sent to recruit participants, I provided all men with the letter of informed consent (see appendix C). I explained both the letter of 
information and the letter of informed consent before I proceeded with the interviews. I informed all the research participants of the premise of the research, what the research hopes to accomplish, as well as what their participation in this inquiry entails. I asked the participants if they had any questions or concerns about their participation in this research, and once they all understood both letters and the procedures of the interview, I asked them to sign the letter of consent. All of the men signed the letter of consent. I also explained to the men that they have the freedom to choose not to answer any of the questions and I made clear that they were free to terminate the interview at anytime during the interview without repercussions.

The interviews were all tape-recorded with the participants Informed Consent and all of the data was transcribed for analysis. I informed each participant that I cannot guarantee their confidentiality because I will use quotes from the contributors in the thesis. However, I employed the method of using numbers, which according to Van den Hoonaard (2002) increases the participants' anonymity.

\section{Data Analysis}

I organized, examined, and analyzed the research data by using the analytical technique of thematic analysis. Braun and Clarke explain, "thematic analysis is a method for identifying, analyzing and reporting patterns (themes) within the data" (2006, p.79). Boyaltis (1998) explains "thematic analysis is a way of seeing" (p.3) the data. The data analysis involved several processes that helped to identify the themes within the data and provided the means to organize 
the information in this thesis. The initial step that I undertook occured during the interviews when I took notes on interesting comments and points. This allowed me to probe or ask further questions during the interviews for further clarification on specific statements or to gain an increased understanding of what the men were implying. In addition, I took notes during the interview to facilitate the analysis once the interviews were all transcribed. During the transcribing of the data I also took notes on interesting comments and took note of emerging concepts within the interviews.

I read, and re-read all of the participants' transcripts to gain a better understanding and feel for the data. Once I had an understanding that encompassed all of the data from the participants, I began analyzing the data to examine how they answered the main research questions. Kirby and McKenna explain, "to do analysis, the data must be divided into portions that are manageable" (1989, p.135). Kirby et al. further note "the continuous process of comparison and linking of bibbits [i.e., quotes, statements, etc.] helps researchers to understand the specific and overall properties, patterns and relationships between data and between groups of data" (1989, p.135). As such, I examined how the research participants answered all questions during the semi-structured interviews and began to code the data for relevant themes that relate to the main research question of this study. I colour coded the emerging themes in the data while examining the research data. Once the themes were identified, I grouped the themes into three sections to help organize and manage the data. There were six main themes that addressed my principal research 
question: "what are the perspectives that can increase men's participation in the prevention of violence against women in New Brunswick's local communities"? The main themes that emerged from my data are: men's understanding of masculinity in our society; the role of power and control in violence against women by men; the role of patriarchy associated with violence against women by men; men believing in the importance of working with women; the importance of working as a community; and reframing the language associated with violence against women and men. The three sections that I grouped these themes into are: how the men understand violence against women, how men understand and frame masculinity, and how the men believe we can increase other men's participation around the prevention of violence against women by men. I then examined and organized the research data within each of these three sections. I reviewed the themes and each of the sections and wrote extensive notes regarding the data. This provided me with the opportunity to clarify and organize each section. The result of this process was the development of a story that provides an understanding of the principal research question. Once I had a conceptual understanding of the data and how it relates to each of the themes, I was able to develop a structural analysis and link the data to theory. This process involved critically examining the data of the participants, examining the gaps and strengths of their conceptualizations when linked to a socio-political understanding, framing how they conceptualize masculinity, understanding how the men view violence against women, and the processes they see fit for increasing other men's participation in this field of inquiry. Throughout the writing 
stage of the thesis, I had to re-familiarize myself numerous times with the data by re-reading on several occasions the data of the research participants. This provided me with the opportunity to expand on some of the themes identified and to re-examine some of the data and themes that I pursued in my analysis.

The following three chapters are based on the data from my interviews with the seven men who participated in this study. The next chapter, Framing of Men and Masculinity is an examination of the themes that forms the section for how men understand and frame masculinity. 


\section{CHAPTER THREE}

\section{FRAMING OF MEN AND MASCULINITY}

This chapter examines the participants' understanding and perceptions of men and masculinity in our society and will begin with an examination of the data from six of the seven participants. The chapter will also examine how the men view the socialization of masculinity and how they perceive the ways that cultural industries frame masculinity. This examination is important for answering the principal research question: "what are the perspectives that can increase men's participation in the prevention of violence against women"? This research suggests that in order to increase men's participation in the prevention of violence against women, community workers must take into account how men frame masculinity in our Western society. Incorporating a structural social work theoretical understanding of violence against women by men is in essence a political project founded on social justice and social change. Therefore, examining how the research participants understand and construct masculinity provides the opportunity to incorporate engagement strategies that challenge the social construction of masculinity, as well as the structural aspects that contribute to violence against women by men.

I will illustrate that six of the seven participants' understanding of masculinity links to the concept of hegemonic masculinity "which reflects the dominant and therefore most influential definition of masculinity in our culture today" (Wolf-Light, 1999, p. 140). This chapter also explores divergent 
understandings of masculinity from one of the seven research participants. I will demonstrate that this alternative understanding of masculinity derives from the writings of the mythopoetic men's movement that argues a return to the traditional constructs of the masculine role within society. The chapter ends with a critical analysis on the participants' understanding and framing of masculinity within Western society. I also highlight the importance of how the framing of masculinity is an important aspect to eliminating violence against women by men and in developing processes that facilitate the engagement of men in antiviolence work in their communities.

\section{Participants' Framing of Masculinity}

A cornerstone in the literature pertaining to violence against women perpetrated by men is the social construction of masculinity. Interestingly, when I asked the participants how they view their role in the process of preventing violence against women, the theme of challenging the construction of masculinity emerged in the interviews with all of my participants. Six of the seven participants discussed elements associated with the notions of hegemonic masculinity.

The participants in my research describe some of the processes that support the dominant narrative in Western society regarding what it means to be a so-called 'true' man. The imagery of men within society presents men with challenging and contradicting notions. Participant \# 4 explains, "I've got all [of] these models, all [of] these images of what it is to be a man. [I have to be] physically strong, confident, make a lot of money, be successful". According to participant \# 6, our society provides perceptions that men cannot show emotions 
and must strive with expectations that are unrealistic, such as always being tough, men can never cry, men can never show feelings, men can never be vulnerable. Participant \# 6 explains that, "as a man ... you got to suck it up, you got to be strong, you got to be confident, put on the face". Participant \# 2 provides this explanation, "most men feel that they have to prove themselves, they [are] giving [the] role of, you know, solve the problem and we will fix it, and we sometimes do not know, and so we pretend, and I think sometimes we need to show a face of being the strong one". According to participant \# 7, our Western society "spends more time with either build[ing] up the body or the brain, or both, and nobody ever thinks about the heart until maybe on their deathbed". In other words, Western society places greater values on men who are either or both, physically strong and of highest intellect and minimizes the importance of men building the heart, such as empathy and love.

These participants provide accounts that men in our society are presented with unrealistic notions of masculinity. Michael Kaufman develops a term synonymous with the ideas of hegemonic masculinities by deeming these social constructions as 'hallucinations of masculinities' (1993). Kaufman uses this term because in his view, hegemonic masculinities are in part illusions of a so-called 'real' masculine self, whereby men attempt to portray and practice these hallucinations of masculinities through their behaviours and beliefs.

These social constructions of masculinity provide the framework for justifying and promoting violence among other people. Research suggests a link between violence against women by men and hegemonic masculinity (Connell, 
1987 \& 1995; Pease, 2003; and Kaufman, 1993). As participant \# 7 states, "it is really important in this culture, in this society, what being a man is, you know, which is basically being violent". Kaufman asserts, "men's violence is the most dramatic display of the destructive potential of the hallucination of masculinity set in a patriarchal world" (1993: p.160). Furthermore, Hong's dissertation illustrates that men with a traditional view of masculinity, have a greater acceptance and expectation of aggression and violence (1999). Participant \# 1 believes that violence against women by men is partly occurring because of the social construction of masculinity in our society. He states:

There [are] just lots of questions of how we view masculinity as well in terms of power and such that in relationships men can seek power by being violent against or abusing in some ways someone who is [or] who they perceive as weaker than themselves or more vulnerable. So in relationships, that can lead to violence from a male partner to a female partner. [lt is] sort-of partly based on how we frame masculinity in our culture.

To comprehend these social constructions that reinforce and support violence against women by men, it is important to examine the historical context that is associated with the development of gender in our society.

Participant \# 1 provides his view of how gender is constructed within western society: "within my culture, it is very much Christian, western, European, mostly British ideas about the role of fathers, role of mothers, what boys do, what girls do". James Messerschmidt (1993) explains that hegemonic masculinity is defined within a historical context:

[In] contemporary western industrial societies, hegemonic masculinity is defined through work in 
paid-labor market, the subordination of women, heterosexism, and the driven and uncontrollable sexuality of men. Refined still further, hegemonic masculinity emphasizes practices toward authority, control, competitive individualism, independence, aggressiveness, and the capacity for violence. (1993, p.82).

One consequence of framing masculinity in terms of hegemonic masculinity is the idea of domination. It is important to note that the notion of domination links to the concept of patriarchy. According to participant \# 5, "a lot of the problems with domestic violence come out of the patriarchical tradition which has said this is what men can do and get away with". Examining this statement closely, we can see that participant \# 5 is highlighting the idea of privilege. Some men in our society hold the notion or perception of being the 'king of the castle' in their household, and have a sense of entitlement which claims power over at the expense of women. Furthermore, the idea that men own women is another trait of patriarchal notions. As participant \# 1 states, it is the "whole possessive idea, you are mine". This participant is explaining the patriarchal family structure that defines and reinforces the oppressive gender division in the Western society.

A major issue of violence against women in our society derives not only from how we, as a society, define masculinity, but also how gender is constructed and presented. What we perceive in our societies to be correct or proper with regards to masculinity, can in fact be unrealistic social constructions. As participant \# 6 explains, "there are stereotypes [of being men] that [in] some way are getting more pronounced. They are more crystallized, like if you see the 
robots, like the Terminator". These masculine constructions of masculinity can range from believing and behaving with notions that men are the kings of the household, men must control those who are weaker and subordinate to their 'real masculine' self, or men can use violence and aggression towards women and other subordinate others.

According to the participants, the cultural industries (e.g., mass media) propagate the constructions of masculinity and femininity in our society. Participant \# 2 explains "we idolize some people, especially you got North Americans [we are] influenced by Hollywood, by the media, I think those are governing powers right now". Discussing the idea of the construction of gender as a whole, participant \# 1 specifically mentions examples from the media in relation to how they frame the feminine and the masculine. Participant \# 1 states that the media portrays the idea that "men are supposed to be dominant [and] women are supposed to be subjugate or accepting of dominance". This participant understands that a key aspect of the construction of masculinity in our society derives from the patriarchal tradition that reinforces the subordination of the other, who is viewed as the weaker gender, for example, woman or perceived weaker masculinities, such as, homosexuality.

According to participant \# 5 , those processes that perpetuate gender subordination in our society are not improving. Rather, he believes "the male and female roles are becoming more stereotyped", and a key reason is how the mass media propagates the masculine and feminine. Those gender constructions are what participant \# 5 classifies as the "common stereotype or the common images 
[where] the male [is] Rambo, Schwarzenegger, [or a] WWF type figure [with] over the top muscles and the woman is plastic surgery enhanced." These gender constructions are propagating the constructs of "hyper masculinity, the six-pack and the 46-inch chest and the muscles here, and the women who has cosmetically enhanced her body so that she's got big breasts and a tiny waists" (participant \# 5). As participant \# 6 explains in reference to the cultural image of the Hollywood man, "I don't know who he is, it's not a man, but it's something". Michael Kaufman (1993) supports this observation by noting that we as a society sustain these unrealistic characteristics by sheer allure and glorification. Nonetheless, resisting and challenging these social constructions of masculinities is possible. Participant \# 6 explains:

I do not think it is within our grasp in the media in the foreseeable future to get rid of, but what could happen is that more and more people, men both old and young men, start taking that as status quo that more openly and acknowledge that there is something wrong there. That this is not what I am. That is not what it means to be a man, this terminator or whatever.

This participant acknowledges the powerful influences in regards to the propaganda that distorts masculinities in society. However, he opens up possibilities of resistance by explaining that one of the means to dismantle the illusions of masculinities is by challenging and reframing the notions associated with masculinities in our society. Participant \# 4 suggests:

In terms of our self-image, all of those dynamics, all of those realities. I think that is really an interesting conversation to have. Around what it is being a man today, and how do we get our maleness in a 
respectful way for not only your partner, but also [in] the community.

In other words, he is arguing that men need to begin processes for reframing masculinity towards more realistic masculinities.

Participant \# 1 explains, "what needs to happen is to work at reframing masculinity, or ideally getting rid of the box". The participant explains that one of the major roles that men must take on for developing prevention efforts regarding violence against women is to reframe masculinity. Participant \# 1 further adds that in his opinion, the framing of masculinity is "one of the main causes of the problem" associated to men's violence towards women in our societies. The concept of 'gender boxes' and hegemonic masculinity, as discussed by Connell (1987 \& 1995) reinforces unrealistic and oppressive practices and behaviours of the masculine and feminine.

Participant \# 1 also explains, "as much as our framework of masculinity is a problem, so is our framework of femininity, they work together". Jane Flax (1990) discusses this problematic of social relations by explaining, "men and women are both prisoners of gender, although in highly differentiated but interrelated ways. That men appear to be and (in many cases) are the wardens, or at least the trustees within a social whole, should not blind us to the extent to which they, too, are governed by the rules of gender" (p.45). Participant \# 5 states, "sexualization is a sort of dichotomous understanding. Men do this, and women do that". Consequently, "anything which tries to cut through those old stereotypes and get kids mixing, boys and girls, men and women together to break down all those everyday power imbalances, is the oppression that's built 
into our society already along gender lines" (participant \# 5). Accordingly, participant \# 1 suggests, "if two people [are] trying to fit those roles together and get together, it is very likely that the person who is dominating and the person who is being timid, that the dominant can often turn to various forms of violence or dominance". Therefore, participant \# 1 suggests in situation of violence towards women by men, a woman may "see herself as needing to be subjugated to men, this can breed violence". This argument reflects the concept of hegemonic masculinities since society portrays the notion of subjugation, which suggests that men have the right to use power over the other person who is viewed as their subordinate. Furthermore, the subjugation of the weaker gender also derives from the concepts of capitalism that believes in competition that reinforces the ideas of power over with the concept that only the strong survives. Similarly, participant \# 1 believes we need to work at "unframing gender, not just masculinity". Participant \# 1 also suggests that we need to deconstruct the concept of gender and disrupt the prevalent notions of what it means to be a man or woman in our society. This process of deconstructing gender involves identifying unrealistic notions perpetrated by our society (e.g., men are tough and women are weak; or men's work is more valued and paid more than women's who are doing the same job). It also involves developing processes that value and respect different forms of masculinity and femininity. Therefore, the process of dismantling gender as a whole must be taken into account in the struggle to end violence in our communities. Consequently, the constructions of different 
hegemonic roles between the masculine and feminine need to be reframed within a non-hegemonic discourse.

To be able to reframe the hegemonic constructions of masculinity, it is important to understand the main concepts of hegemonic masculinity. This understanding allows us to develop processes to begin dismantling the social constructions of oppressive masculine constructions. This understanding is vital in order to develop strategies that challenge the structural elements of capitalism and patriarchy that continually oppress women in the Western society. Examining the writings on the concept of hegemonic masculinity in greater scrutiny, provides the framework for community workers to develop processes to raise the consciousness of men with the goal to increase their participation in elimination of violence against women by men.

In 1987, R.W. Connell explained that there is "an ordering of versions of femininity and masculinity at the level of the whole society, in some ways analogous to the patterns of face-to-face relationship within institutions" (p.183). Connell further states, "their interrelation is centred [sic] on a single structural fact, the global dominance of men over women" (1987, p.183). Explaining this phenomenon, Connell borrows the term and concept of hegemony from Antonio Gramsci's (2003) groundbreaking work. According to Connell, "hegemony means a social ascendancy achieved in a play of social forces that extends beyond contests of brute power into the organization of private life and cultural processes" (1987, p.184). 
Connell (1987) highlights the distinction between the concepts of ascendancy and hegemony, in that ascendancy is embedded in our society by means of organizing the societal structures such as religion, mass media, and wage structures. Two important distinctions or clarifications are needed when discussing the phenomenon of hegemony and masculinity. This hegemonic societal organization is not necessarily referring to domination over others that draws from forces upon the subordinate. Connell notes:

Hegemony does not refer to ascendancy based on force, it is not incompatible with ascendancy based on force. Indeed it is common for the two to go together" and second, "hegemony does not mean total cultural dominance, the obliteration of alternatives. It means ascendancy achieved within a balance of forces, that is, a state of play. Other patterns and groups are subordinated rather than eliminated. (1987, p.184).

Gramsci's concept of hegemony "refers to the cultural dynamic by which a group claims and sustains a leading position in social life" (Connell, 1995, p.77).

Connell (1995) explains that the ascendancy process provides the essential aspects or structures to what he coined as 'hegemonic masculinity'. In terms of masculinity, this occurs because the historical concepts of men and their role within society purports that they are superior and powerful compared to women and other subordinate masculinities.

The essence of 'hegemonic masculinity', according to Connell (1987), is reinforced and supported by the different forms of subordinate masculinities, such as homosexuality, and its relationships with women. Furthermore, Connell (1987) explains that this interaction with different type of masculinities 
demonstrates an important function of patriarchy. Connell further develops his argument by stating that "hegemonic masculinity can be defined as the configuration of gender practice which embodies the currently accepted answer to the problem of the legitimacy of patriarchy, which guarantees (or is taken to guarantee) the dominant position of men and the subordination of women" (1995, p.77). This, according to Connell, results in "the global subordination of women to men that provides an essential basis for differentiation. One form is defined around compliance with this subordination and is oriented to accommodating the interests and desires of men" (1987, p.183).

Connell clarifies that the concept of hegemonic masculinity "is not necessarily what powerful men are, but what sustains their power and what large numbers of men are motivated to support" $(1987, \mathrm{p} .185)$. Therefore, the concept of hegemony supports and reinforces the idea of consent. As Nigel Edley explains, the notion of hegemony "assume[s] the status of facts, taken for granted as true or accurate descriptions of the world" (2001, p.190). Nevertheless, men support these notions as "it seems likely that the major reason is that most men benefit from the subordination of women, and hegemonic masculinity is the cultural expression of this ascendancy" (Connell, 1987, p.185). Connell reminds us that these cultural expressions of ascendancy do not suggest meanness towards women; rather, "what it does imply is the maintenance of practices that institutionalize men's dominance over women" (1987, p.185). However, the concept of hegemonic masculinity also includes constructions of alternative masculinities such as subordinate masculinities. For 
example, 'being homosexual' is viewed as a subordinate form of masculinity and the 'normal' form of masculinity is heterosexuality.

Donaldson explains that heterosexuality and homophobia are the fundamental aspects of "hegemonic masculinity and any understanding of its nature and meaning is predicated on the feminist insight that in general the relationship of men to women is oppressive" (1993, p.645). As Connell states, "hegemony relates to cultural dominance in the society as a whole. Within that overall framework there are specific gender relations of dominance and subordination between groups of men" $(1995, \mathrm{p} .78)$. Therefore, a fundamental aspect of hegemonic masculinity is the notion that women's existence is as sexual objects for men (Donaldson, 1993). Hence, the concept of hegemonic masculinity supports the idea that men have an entitlement and the possession over women. This subordination, according to Crooks, Goodall, Hughes, Jaffe, and Baker (2007), plays a role in all levels of society (e.g., individual level, community level and so forth) and is linked to the perpetration of violence against an 'other' (e.g., women or homosexual). Furthermore, Bob Pease (2003) suggests that societies with extreme polarities between the masculine and feminine have the greatest inequality and violence. Hence, this subordination process perpetrates violence against women by men. Consequently, Pease notes, "this analysis has significant implications not only for preventative approaches to men's violence but also for the establishment of gender democracy across all levels of society" (2003, p.131). In other words, analyses, which take into consideration the dichotomies between the masculine and 
feminine are fundamental not only for the prevention of violence against women by men but also for social justice among the genders.

\section{Alternative Framing of Masculinity}

One of the seven participants in this research had a divergent understanding of masculinity when compared to the other interviewees. Participant \# 3 believes that violence against women by men happens because of power. However, the attention to power does not derive from a feminist theoretical framework; rather, it is formed by the concepts that men as a group are losing power within society, and as the Mythopoetic writers suggest, men are trying to reclaim their sense of lost within society because of the negative impacts from the feminist movement. Nonetheless, participant \# 3 explains that we as a society must not condone violence and to address the root causes of violence we must address the loss of power in men. Participant \# 3 states:

I think that men feel usurped, like as if they have been disposed of a throne. I don't know that they really know that consciously but I think it is an unconscious feeling. It is like you know where is my power? Where has it gone?

This participant articulates that men are being reactive, whether they are conscious of it or not, towards women because of their loss of power within society and their household. Therefore, participant \# 3 explains that, "what is happening with men is that they are grieving the lost of their power".

Consequently, according to participant \# 3 "we lose power [and] we usually try to get it back and sometimes we do it in positive ways, and sometimes we do it in negative ways". 
This framing of the male identity within society illustrates an interesting component to the concepts of hegemonic masculinity. Connell states that the mythopoetic movement is "political not just because of its patriarchal imagery, but because of what is centrally an attempt to create or restore a particular gender configuration of practice" (2002, p.144), in other words, to uphold the basic construction of the male identity within society. Therefore, the statements by participant \# 3 confirm his view that men react and use violence when they want to reclaim their sense of power and control within society. The solution to end violence against women, according to participant \# 3 , is that men need to develop new skills and tools to deal with their loss of power. In other words, participant \# 3 argues that men must reclaim their sense of entitlement within society.

To gain an understanding of the Mythopoetic movement, Capraro (1999) believes that we must examine the writings of Robert Bly, who is the one of the main writers associated with this perspective. Robert Bly (1990) argues that the Mythopoetic movement:

....asserts that concepts of masculinity have resulted in two unacceptable models of what it means to be a man: the 50s male, who represents the "traditional" man as father and provider, and the "soft" male, who has connected with his feminine side with the aid of the feminist movement. (p.84, quoted in Capraro, 1999).

Therefore, the two concepts create a sense of dissonance within the male identity and establish a feeling of loss within society. In turn, this sense of masculine loss exemplifies processes of grief and hurt, as the men are 
attempting to reclaim this loss by using unhealthy behaviours, such as violence towards others with the inherent goal of reclaiming their power and male identity within our societal construct (Bly, 1990). Connell (1995) suggests that the Mythopoetic perspective argues that men must reclaim their lost identity within society by reclaiming the men's primitive emotions. This process of reclaiming their primitive emotions as men is explained by Bly's concept of the Wildman.

Thorne-Finch explains that Bly's idea of the Wildman emphasizes:

The true inner male essence - is not a violent entity. The Wildman purportedly operates from a point of strength, while offenders, being disconnected from the Wildman, are weakened and insecure, and thus more likely to strike out (1995, p.227).

Therefore, the primordial and true masculine identity is the Wildman.

Consequently, Robert Bly argues that to reconnect with their primordial male sense, men must participate in male gatherings and mythical rituals. For example, Thorne-Finch (1995) provides a description of the male gatherings and rituals by stating:

Men gather in groups to build and then wear masks depicting their inner man. Drums of all sizes either are constructed or available for ceremonial drumming intended to dispel the spirits of contemporary masculinity and invite the reawakenings of a long-lost, and undiluted, masculine essence. (p.226).

In essence, Bly believes in using these gatherings with the purpose to heal and release the male primitive emotions (i.e., the wildman) in which this process reclaims the inherent male identity in our high pace and increasingly globalized society. 


\section{Conclusion}

The purpose of this chapter was to review how the participants view masculinity, indicating how the majority of men interviewed, understand masculinity as deriving from a misrepresentation and illusionary ideals of what it means to be a man in our Western society. The participants discussed the importance of understanding the societal constructs of masculinity and femininity in order to develop engagement strategies for men that will challenge the structural elements within society. Therefore, the examination of gender is important for answering the principal research question: "what are the perspectives that can increase men's participation in the prevention of violence against women"?

I used the concept of hegemonic masculinity developed by Connell (1987 \& 1995), to explain this ascendancy process that constructs the notion that heterosexual men are more powerful than other subordinate genders, such as women. Although the men named the masculine illusion, only three of the seven participants understand the socio-political constructs that are associated with hegemonic masculinity. Participant \# 1, 5, and 7 highlighted an understanding that went beyond the symptoms of hegemonic masculinity, by explaining some of the processes that connect to the structural aspects of violence against women, such as the idea of patriarchy and capitalism. This will be made clearer in the following chapter in which I examine how the men understand violence against women between the personal and socio-political dimensions. On the other hand, participant \# 2, 4, and 6 name the symptoms of hegemonic masculinity without 
naming or implying the structural influences, such as the role of patriarchy, in framing the illusion of masculinity. The chapter also discusses other aspects of hegemonic masculinity by examining how the influences by the cultural industry with its imagery of masculine men impact the notion of masculinity in society.

In addition, this chapter discussed an alternative construction of masculinity by one participant, who argues the ideals of the mythopoetic movement. This participant understands the current process of the masculine self as deriving from a sense of loss and grief within the male body. As such, this process of loss and grief results in men as a group, whether consciously or unconsciously, in a sense of urgency to reclaim the male rightful place within society. This sense to reclaim the male role within the household and society results in men responding at times to unhealthy behaviours by utilizing violence towards women to 're-adjust' their rightful place as men. The chapter expanded this argument and illustrated that this approach to both the construction of masculinity and the prevention of violence against women does nothing to challenge the patriarchal ideals of male privilege within society. Rather, this line of reasoning results in the enforcement the hegemonic masculinity construction of the male identity.

Six of the seven research participants argued that one way to prevent and stop violence against women by men is to begin processes that challenge the social construction of hegemonic masculinity. These participants illustrate that to eliminate violence against women, more emphasis is needed on challenging notions of the masculine figure within our Western society. Furthermore, some 
participants argue that we must address not only the construction of masculinity,

but must also challenge general ideals of the feminine body, and more importantly, gender as a whole.

The process to challenge configurations of genders as a whole must involve approaches that are in practice holistic. Such an approach can be developed by gaining insights from anti-racist writings to break the cycle of oppression deriving from gender lines. Chris Weedon notes:

The main lesson of black feminism and feminisms of colour for white women is that they must take responsibility for racism. To refuse to acknowledge racialized difference, even for the best of motives, is an inadequate response, as is the tendency to see race and racism as black societies problems. To recognize the social and cultural status of the category 'white', which most often seems natural to white people, involves conscious effort on the part of white women. (1999, p.176).

The argument by Weedon provides fundamental notions that must be incorporated in the struggle of men to end violence against women perpetrated by men. Therefore, men must recognize the social and cultural status associated with the category 'men', which in our contemporary Western society signifies, for example, the ideals that men must be strong, in control, superior, violent, in other words, the values and beliefs that supports the constructs of hegemonic masculinity. Consequently, men must make conscious efforts to challenge and resist the formulation of 'hegemonic masculinity' since it perpetuates the notions of sexism, violence, and heterosexism as examples, but also must constantly strive to challenge these constructions at a structural level; whether individually 
or collectively. The challenge, however, is that only three of the seven men bridge the connections between the personal spheres and socio-political structures that are associated with violence against women by men. The four of the seven participants who lack a critical analysis tend not to disrupt the social construction of masculinity and in effect support and reinforce the dominant discourse pertaining to masculinity in our society. This finding is significant when considering the locations of each research participant. They are involved to some capacity in the work to eliminate violence against women by men. It is important to note that Dankworth and Rausch (2002) explain that working towards a socially just society to end gender discrimination and violence, any social justice movement must acknowledge and challenge the inherent concepts of privilege that men have within our patriarchal society. Consequently, resisting and challenging these social constructions is part of taking responsibility as men to become allies in the struggle to end violence against women by men.

To answer the principal research question: "what are the perspectives that can increase men's participation in the prevention of violence against women", there is a need for further examination of the research data. The following chapter is an examination of how the men who participated in this study understand violence against women by men. This examination is imperative to scrutinize carefully because the goal of this study is to develop processes that not only increase men's authentic participation to eliminate violence against women by men, but also work for social justice and strive towards social change that will challenge the structural elements that oppress women in our Western 
society. Therefore, the following chapter, Men's Understanding of Violence Against Women is an examination of how the male research participants understand violence against women in our society. 


\section{CHAPTER FOUR}

\section{MEN'S UNDERSTANDING OF VIOLENCE AGAINST WOMEN}

This chapter examines the research participants' understanding of violence against women in our society. This examination provides the opportunity to examine whether the research participants understand violence against women by men as deriving from the structural elements that support and reinforce the oppression of women in our Western society. This examination is important in the development of engagement strategies that are founded on social justice and principles of social change to answer the principal research question for this study. The chapter begins with a general overview of the perceived prevalence of violence against women in Canada, and more specifically in New Brunswick. The purpose of this discussion is to examine if the participants understand that violence against women is greater than the official government statistics. In this chapter a discussion follows on how the men who participated in this research understand violence against women. The chapter will examine the men's understanding of violence against women at the personal level by using the Power and Control Wheel, which is a classification tool developed by Pence and Paymar (1986) to understand interpersonal violence committed by men towards women. A major assumption with the Power and Control Wheel is that violence against women is also influenced by societal structures that perpetuate violence. As such, the chapter discusses the sociopolitical understanding of the research participants and examines if they make 
the connections between personal violence and the structural influences in society that supports violence through the oppression of women. The chapter also addresses how the men understand the concepts of the patriarchal order within society. The chapter will conclude with an analysis of the data by examining the strengths and the gaps of the men's theoretical understanding of violence against women from a personal and socio-political constructs, which I will argue is a vital component for social change that is influenced by social justice.

\section{Perceived Versus 'Actual' Prevalence of Violence Against Women}

All of the research participants' understanding of the prevalence of violence against women illustrates a common theme that the official statistics are not illustrating a 'true' picture of violence against women. Participant \# 6 states "I guess common statistics [are] one in three or one in four. I think that in many ways [violence] is higher than that. There are very different forms, pseudo forms of violence and in the end I think they all impact. It is there, violence is part of our life and it defines life". Similarly, Participant \# 2 argues:

The rate, it fluctuates, I think research at one point [the] Status of Women had some research saying one out of ten women. It depends how you measure violence. If you consider the verbal or psychological violence, then I would say [violence] increased. What I think one in ten would possibly be more like the physical violence and of course, sometimes it involves the sexual areas.

As participant \# 7 states, "there's all kinds of forms of violence". Therefore, these men understand that violence is more than physical, and, in their opinion, the 
statistics do not capture the 'actual' extent or reality of violence against women in our communities.

According to Violence Against Women Survey by Statistics Canada, "39 percent of women over the age of 16 have experienced some form of sexual violence; 54 percent of girls under the age of 16 have experienced some form of unwanted sexual attention; and 24 percent have experienced rape or coercive sex" $(1993$, p.6). Furthermore, the only sexual assault crisis centre in New Brunswick, the Fredericton Sexual Assault Crisis Centre (FSACC), in a 2004 report, discusses research on women and indicates that 17 percent have experienced incest (Russell, 1996), and girls with disabilities are four times more likely to be sexually abused than girls without disabilities (Razack, 1994, p.6). In addition, the New Brunswick Advisory Council on the Status of Women (NBACSW) explains that in 2004, 81 sexual assault cases were reported per 100 000 people in New Brunswick, compared to the national rate of 74 sexual assault cases per 100000 (2006). Statistics illustrate similar high rates of prevalence of other forms of violence against women in New Brunswick. The NBACSW (2006) states that in New Brunswick there were 879 incidents of woman abuse reported to the police in 2004 , which increased from 772 in the previous year.

Furthermore, 1012 women accessed one of the 17 transition houses in the province (NBACSW, 2006). In addition, in 2004-2005, two out of three women who required the services of the transition houses were 40 years old or younger (NBACSW, 2006). 
Therefore, when examining the understanding of men regarding their beliefs about the rates of violence against women and the statistical prevalence summarized above illustrates an interesting theme on how each participant views sfatistical rates pertaining to violence. Although the men do not identify or 'accurately' quote the selective statistics that I identified above, for the most part, they believe that the statistical rates from research institutions and government bodies are in fact a misrepresentation of the actual prevalence of violence against women in their communities. This is important because the under reporting of violence against women by men results in minimizing the prevalence of violence towards women by men. By minimizing the prevalence rates, government institutions, such as the criminal justice system, can make the argument that although violence against women by men happens, it is viewed as isolated cases and the system argues that its response to address these issues are sufficient without addressing the structural elements of violence against women.

DeKeseredy \& Schwart (2002) and Johnson (2002) explain statistical figures of violence against women, such as the Canadian National Survey only reflect the reported cases by women of violence, not the actual prevalence which would be much higher. As Holly Johnson states, "police statistics are problematic because, for a variety of reasons, a very significant proportion of all types of crimes are not reported to the police, many of which involve serious harm to victims" (2002, p.21). DeKeseredy and Schwartz (2002) also emphasize in their study, the statistics on violence against women "are high, as is the case with all 
survey statistics on woman abuse, they should be read as underestimates" (p.115). All research participants supports this idea because they illustrated skepticisms towards 'official' government statistics of violence against women by men and believed they are underestimating the prevalence rates.

Examining how the men understand the prevalence of violence against women in Canada is important because it illustrates the level of consciousness of the men in this study regarding this issue. A cornerstone of consciousnessraising is attempting to identify and provide a clearer picture of the reality of one or more specific problems. Therefore, by gaining an understanding of the prevalence of violence against women by men in Canada, and more specifically in New Brunswick, helps to put into context the seriousness of the issue.

\section{Power and Control Wheel}

The Power and Control Wheel derives from the Duluth Domestic Abuse Intervention Project initiated in Minnesota during 1980s (Paymar, 2000; Pence \& Sheppard, 1999). Ellen Pence explains that the group "tried to shift away from seeing violence against women as the problem of a few psychological distorted men and bad marriages, by linking men's violence toward their partners to other forms of domination - class, race, gender, and colonization" (2005, p.388). The Power and Control Wheel was developed through interviews of over 200 women who were battered by men.

Ellen Pence describes the classification tool that highlights the different forms of violence against women, and explains that the Power and Control Wheel illustrates a system of tactics that men who are abusive towards women 
use in their relationships (2005). This system of categorization has nine aspects depicting the abuser's most controlling and abusive tactics. The nine categories are: emotional abuse; economic abuse; sexual abuse; using children; threats; using male privilege; intimidation; and physical violence (Pence, 2005). Furthermore, she states, "men who batter use a system of abusive tactics to control their partners. Violence is rarely used to the exclusion of other controlling and abusive tactics" (2005, p.377). Pence also states "the use of physical attacks, whether frequent or sporadic, reinforces the power of other tactics such as emotional abuse, isolation, sexual abuse, and threats of taking the children" (2005, p.378).

All of these different tactics complement and reinforce each other in an abusive relationship which has the potential to turn itself into physical violence towards women by men. Hence, the general characteristics of these systems of tactics derive from the concept of power and control.

Orme, Dominelli, and Mullender (2000) explain that the Power and Control Wheel is founded on feminist principles and attempts to link "a hybrid of cognitive behavioural work to achieve individual change, on the one hand, and education to put this into a socio-cultural context on the other" (p.97) when working with violent men. According to Orme et al. (2000), Pence and Paymar's model reflects the belief that both aspects, individual change and education on the sociocultural context, need to be combined "so that men can both stop being violent and stop believing that women should be compliant" (p.97). Therefore, the model when used with the principles of feminism or pro-feminism, works with individual 
men to change their behaviours and attitudes regarding women. Within this framework, we can then begin to examine how the men understand violence from a personal level and how they interpret the socio-political level associated with violence against women in our society.

\section{Men's Personal Understanding of Violence Against Women}

The research participants do have a general understanding of violence as illustrated in the Power and Control Wheel. All seven men discussed and highlighted that violence against women takes different forms. Describing these different types of violence participant \# 2 explains that "there are different layers, and there are different types". Participant \# 6 states that the "common one is physical violence, [but] it can be emotional or social". Therefore, the statement articulates the understanding that violence is beyond physical actions, such as hitting, biting, or pushing. This continuum is further clarified by participant \# 2 when he provides examples of social and societal forms of violence as "any type of racist comments or sexist comments, when you're aiming at [an] individual or group and you're trying to demonize them in any way".

This clearly illustrates that the participants' understanding of violence goes beyond the physical forms; rather, violence is any form of action that reinforces power over another person, for example, demeaning another person with the goal to impose one's notions or worldview over another. Research participant \# 2 says that this occurs "because when you are trying to do that, you are trying to lift yourself, you are trying to say you are better, or you are that stronger or superior." In other words, violence is perpetuating the idea and practice of power 
over because they are trying to assert their strength and position within their relationship.

Pence explains that abusive men have intentions to hurt and depersonalize women (2005). Participant \# 4 describes this in the following manner "if no matter what I do to gain power over another human being, by virtue of the fact that it destroys, has the potential of destroying another person's integrity as well as their physical [self]". This participant explains that abuse includes actions that are intended to depersonalize the other. According to the Power and Control Wheel, this depersonalizing process results from an abusive man viewing his female partner as an object, which facilitates and justifies physical violence towards a woman because women are viewed as objects.

The men involved in this study also pointed to the exertion of power over another human being as one common form of violence and domination. Participant \# 3 stated, "to me, violence is anything that hinges upon another person's free will", which he followed with the emphatic statement "that's violence". The concept that violence impedes on another person's free will is further clarified by participant \# 4, who explains that violence "has an intent to exert control over someone else and has the impact of hurting them". Furthermore, participant \# 4 explains the notion of power and control. He states that violence "is based on power and control in a relationship with someone who uses power over another". Therefore, in instances of violence against women perpetrated by men, it is the exercise by a man, for example, through physical strength, to control or impede upon a female partner. According to Dominelli, this 
process is "the mechanism through which men exercise power over others" (1999, p.26). Likewise, participant \# 4 states if the "intent is to hurt her and my intent is to make her do what I want to do, then the impact is that it is going to hurt her, and so that is abuse". Kivel (1992) also argues, "violence is the ultimate attempt to control. It is power over" (p.72). The notion of power over can be further clarified by Jill Vickers who notes, "in many cases, violence is an extreme form of the abuse of power in relationships of unequal power. It manifests itself in different ways, with different degrees of intensity, and it cuts across boundaries such as class, race, and ethnicity" (2002, p.238). Kivel further notes "we believe someone has power only if he or she controls something or someone. Control is the key issue in men's lives" (1992, p.72). This understanding of violence against women is consistent with the Power and Control Wheel discussed by Pence (2005), which suggests that violence by men, uses a system of tactics to suppress a female partner.

As we can see, the men who took part in this study understand that violence against women involves a continuum of actions that are deriving from the concepts of the Power and Control Wheel as described by Pence (2005). However, an important concept described by Orme et al. (2000) is that the Power and Control Wheel purpose involves not only an approach for individual change, but also incorporates the importance of education on the socio-political constructs of violence. Therefore, to gain an understanding on how we can engage more men in the struggle to end violence against women, we must 
examine in greater scrutiny how the men in my research understand the sociopolitical constructs of violence against women.

\section{Men's Socio-Political Understanding}

Participants \# 1,5, and 7 linked the concepts of the Power and Control Wheel to the larger societal patterns. These individuals provided a general understanding of the socio-political influences associated with violence.

However, participants \# 2, 3, 4, and 6 did not make the direct connections between the Power and Control Wheel and the structural elements in society. Rather, either they minimized the socio-political influences, or they named one or more symptoms of the socio-political influences without delving into a critical understanding, but viewed these processes as a normal aspect of life.

Participant \# 2 minimized the socio-political influences by rationalizing that violence is a normal part of society and stated that women are also violent:

I do not think that men are the only ones who are doing this. I think all society does. I think that [it is] rare that somebody never made those types of comments. Because of our upbringing, over time we might catch ourselves or watch ourselves a bit more and slow it down. But I think any kid in the school yard is saying something nasty to somebody else. And sometimes [it goes] in circles, sometimes it's just part of life. It just goes on.

This comment illustrates a process of redirecting and minimizing the reality that men are the main perpetrators of violence in our society. Interestingly, although this participant is a professional who works with abusive men and is involved in different preventive efforts, he does not articulate an analysis that is informed from a critical stand point. Furthermore, participant \# 2 argues that violence is 
"part of life. It just goes on", without explicatively providing a critical analysis of the root cause of violence towards women. He illustrates an understanding that violence is greater than the mere physical realms of a man hitting a woman, which was identified earlier in this chapter. However, he suggests that violence is, "sometimes it's just part of life" and demonstrates that violence is viewed as being a normal construct of our society.

Bob Mullaly examines this so-called normal construct of society in further details by borrowing from Thompson's (1997) multi-dimensional framework of oppression. Mullaly (2002) explains that Thompson's (1997) framework has three concepts of oppression in society. The model involves the personal, cultural, and structural as components that "are in dynamic interaction with one another, with each level supporting, reinforcing, and influencing oppression on the other two levels and in turn, being supported, reinforced, and influenced by the other two levels" (Mullaly, 2002, p.48). Therefore, the 'sometimes it's just part of life' as stated by participant \# 2 , suggests that the dynamics of violence in our society is multi-faceted. On the one hand, violence is perpetrated on the personal sphere as discussed earlier, but these violent behaviours are reinforced by the cultural image of masculinity which reinforces the oppressive political structures. For example, the patriarchal view in our society that women are weaker than men, is a process that justifies the subordination of women in our communities. As such, women will have a continuing struggle to gain influence or work in positions perceived in our society as domains only accessible from men. This perception derives from the historical constructs that men are more able and stronger than 
women. It is important to note that the same perceptions are held in abusive relationships in heterosexual relationships, where the men view the women as their subordinate and must be controlled. This dynamic has the potential to lead to physical violence in a relationship perpetrated by the male in the household.

Studies explain that violence is not a mere dichotomy; instead, it involves very complex processes in our society's social constructs. As Jiwani explains, dichotomizing violence against women between physical and emotional "fails to take into consideration the ways in which violence is used in intimate relationships" (2002, p.67). Participant \# 1 states "we have structures that can lead to violence and those are often instilled in our society" and further says "there is something in our society that leads [violence] to be systemic" and "the way men and women interact leads to violence [or] can lead to violence".

Mullaly explains, "violence lies not only in direct victimization, but in the constant fear that violence may occur, solely on the basis of one's group identity" (1997, p.150). Violence then, is beyond the realm of physical actions, such as a man hitting a woman or emotional actions, such as a husband demeaning his wife, rather, violence consists of structural elements that perpetuate the subordination of another group. This subordination is violence because it oppresses a group that is viewed as weaker than another, for example, the notions that men are more powerful and capable than women. Participant \# 1 provides the following explanation to highlight the complexities of violence against women as more than being in the physical realm by stating that violence against women is something "that moves from one point to another". This 
illustrates that participant \# 1 understands violence as a continuum, as a system of actions or as Pence suggest, "a system of abusive tactics to control their partners" $(2005$, p.377) that moves towards physical violence against women in a relationship. However, participant \# 1 goes further by stating that violence against women "is more than just random violence, there are sorts of systems and cultural elements in places that lead to violence, and I see that as a big problem and violence against women is how a lot of violence is manifested in our society". In other words, participant \# 1 views interpersonal violence towards women by men as a mere symptom that is influenced by the structural organization of society.

Jeff Hearn argues that an important assumption derived from the power and control model is that the "intervention is not only about stopping physical violence, as if that is some separate activity; it is about moving away from power and control in all aspects of the man's relations with women. To do that means presenting positive ways of living that do not reinforce power and control" (2001, pp.79-80). Therefore, it is important to examine how the participants view other aspects of men's relations with women in explaining violence.

The importance of examining the men's understanding of the sociopolitical structures is to highlight how men understand violence against women. The reasons for this examination is to determine if it is necessary to have an indepth socio-political understanding in developing strategies for engaging men in initiatives that have the goal of preventing violence in relationships. Moreover, incorporating a critical understanding of violence in society has the potential to 
result in an increase in men's participation to eliminate violence against women by men. However, four of the seven participants do not make direct links to the socio-political influences regarding violence against women. Rather, these individuals understand the behaviours of violent men by identifying the actions of violence but they do not provide an informed critical analysis of society with their understanding of violence against women.

Understanding the relationship between the personal and the sociopolitical is important when working for social change towards social justice. Another important component of the socio-political framework, especially when understanding violence against women is the concept of patriarchy. Therefore, it is imperative there is an examination on how men interpret the relationship between violence against women and patriarchy.

\section{Patriarchal Understanding}

Understanding violence against women committed by men must take into consideration the socio-political influences from society. One fundamental aspect of the socio-political construction of violence towards women by men is patriarchy. Therefore, this section examines if the participants make the connections between patriarchy and violence against women.

A general concept of patriarchy is that woman are viewed as property within the household, and as such, men are entitled to be the ruler of the household. Lerner (1986) explains that patriarchy:

...means the manifestation and institutionalization of male dominance over women and children in the family and the extension of male dominance over women in society in general. It implies that men hold 
power in all the important institutions of society and that women are deprived of access to such power. It does not imply that women are either totally powerless or totally deprived of rights, influence, and resources (p.239).

Although Participant \# 2 does not make any connection between the concepts of patriarchy in our current period in time, he does however provide a historical understanding of the patriarchal family structure. He states that in the past, "the man was the ruler of the household; he was the one making the major decisions and his authority could not be challenged. I think the saying was, every man was the king of his castle". This participant identifies an important framework of a patriarchal family structure; unfortunately, this participant believes that in the past, these structures were prevalent but he suggests that these household configurations have now changed and are no longer dominant in our society.

The influences of patriarchy are not only found in the family structure and the household, but also are prevalent in the public realm. Lundy explains that:

Patriarchy, both a system of social structures and an ideology, in the household and in the public realm, supports the exploitation and oppression of women by men. Women face sexism and stereotyping in their private and public lives. The patriarchal nature of the traditional family is characterized by compulsory heterosexuality, violence against women, and the exploitation of women's labour. Women continue to be portrayed as less capable and intelligent than men, promiscuous, and over-emotional (2004, p.80).

Gilroy similarly sees the relationship between patriarchy and violence by stating, "men's violence toward women has been directly connected with men having a disproportionate share of wealth and power" (1990, p.54). Participant \# 1 provides the following example of a mother who is in a violent relationship, but 
who does not have the means to leave this unhealthy relationship because of lack of financial security. He states, the mothers "salaries is not enough to raise these children and so if I leave this [violent] relationship, what am I going to do? You know, sort of balancing the violence they may be facing against the needs of their children" (participant \# 1). This participant is acknowledging that the patriarchal family is organized in a fashion that oppresses the women because of a lack of wealth and power. Furthermore, participant \# 1 explains that our society is constructed in a manner that glorifies traditional male labour as more important and of higher value. He explains by providing his own experience in the work field that "I think that women do still tend to get paid less than men. I know that a lot of the jobs I have held have been done in fields that are typically, are predominantly women working there and it is definitely a lower pay scale than fields that are predominantly male". He further states that in relationship the difference between paid and unpaid work by women and men "could be a factor, whereas you cannot always quantify what is equal work" (participant \# 1). Thus, Gilroy explains a fundamental aspect of patriarchy, which is a society that views women as being inferior to men, "and as objects of all types of abuse" (1990, p.69). Moreover, Michael Johnson states that another aspect of violence against women is "rooted in basically patriarchal ideas of male ownership of their female partners" (1995, p.284). In other words, making the argument that the ideological foundations of patriarchy are one of the root causes of violence by men towards women in our communities. 
Another concept discussed earlier was the idea that male privilege derives from patriarchy. Participant \# 5 explains "this comes back to how we are born male. We are born [with] privilege". This privilege as mentioned previously is part of the patriarchal order within our society. As in the case of patriarchal structures, participant \# 7 goes further by stating, "that oppression is built into our society along gender lines". This supports Mullaly's (2002) explanation that our societal structures are organized in ways that support the divisions between the status quo and their subordinates. Participant \# 5 who illustrates an understanding of the patriarchal order by reflecting on his personal life experience, provides an example of the divisions among gender lines. He explains, "I came from a patriarchal family". He further states, "I had two sisters and I knew that I could walk out at night by myself. I used to have a part-time job and I would walk home ... but my two sisters, it was like [different] and that was part of their everyday life" (participant \# 5). Therefore, he is making the argument that because he was a male, he had the privilege of walking by himself without the fear of being harassed or sexually assaulted. Participant \# 5 further states that he came to the "realization that the world works differently if you are a female than if you are a male. And that is not fair". The statement by participant \# 5 illustrates an interesting understanding of how society is organized. He is making the connections between the personal lived experiences of his sisters and the oppressive socio-political elements in which society is organized. 
Participant \# 6 explains another understanding of violence against women.

From his perspective, violence against women are the interactions among people in groups within our society, stating:

The interactions with people, with different groups of people, as in any true group of people, will define themselves within this group or that group and if everything else is equal in our society there's male and female and one group will try to win over or be stronger or in control or judgmental. Let's put the negative in this, we all want to be in control, therefore we use the logic; I have to be in control, I will get stepped on, so I will on them. That logic, which we do not have to use, but we usually use, is applied to everything else, whether you are talking about class, education, whether we are talking about race, whether we talk about culture, whether we talk about nationality. It is my group, so I am ok.

In other words, people will associate with people who share similar identities, therefore, participant \# 6 is explaining that people are hostile toward each other because of differences and will try to control one another. In the case of violence against women by men, men are trying to control women because of their differences as a group. Although this participant identified earlier the notion of male privilege as a structured reality within society, his analysis of the root causes for violence against women is lacking. Rather, he believes that the issues of violence relate to how groups of individuals interact among each other and forgoes any socio-political connections.

Participant \# 1 provides the following example to support the notion that violence is more than random by saying 'if I can't get a loan from the bank because I am female, then that is violence because it interferes with [one's] life". 
Participant \# 7 confirms that, violence is " around you. I mean, anywhere ... politicians or religious people or bureaucrats or judges". Therefore, Mullaly suggests that "violence is structural when it is tolerated, accepted, or found unsurprising by the dominant group, or when perpetrators receive light or no punishment. Violence is a social practice when people from the dominant group seek out people from oppressed groups to beat up, rape, or harass" (1997, p.150). Mullaly adds that the goal of structural social change is to "reform institutions and social practices that encourage, tolerate, or enable violence against members of specific groups will require a change in cultural images, stereotypes, and the day-to-day reproduction of dominance and aversion" (1997, p.150). Nonetheless, Lundy states, "focusing on the social and economic context does not imply that individual change work is ignored or set aside. Nor does it suggests that individuals are not responsible for their actions" (2004, p.58). Hence, since the constructs of structural violence delves within the realm of challenging the hegemonic constructions of society, it is not surprising that only a few of the research participants acknowledge or identify these structural forces that enable and perpetuate violence towards women by men. However, as will be discussed in the following chapter, all of the men identified the unrealistic construction of masculinity as one of the main problems that needs to be addressed.

This understanding of violence against women illustrates the differences in understanding among the research participants. An interesting theme of how men understand violence against women in this study emerged, in that four of 
the seven participants do not have a critical or structural analysis of violence against women, rather, they view violence as a breakdown in relationships, personal deficiency of the male perpetrator, or dysfunctional identities. Although some participants do acknowledge elements of socio-political constructs of violence, such as male privilege, they do not have a well-informed analysis that incorporates the critical complexities of violence against women. They only identify general symptoms such as comments that in the past there was a prevalence of patriarchal families without stating that these issues are still current in our society. Unfortunately, such analysis falls short of understanding the interactions between the personal, cultural, and structural realm or spheres. An important aspect to consider is that most of these participants are professionals or para-professionals who work with violent men. Consequently, acknowledging their sincerity and passion to stop violence in our communities is not the issue. The question remains how these individuals can address violence against women if their understanding mainly reaches the symptoms and not the root causes.

\section{Conclusion}

The purpose of this chapter was to capture the essence of men's understanding of violence against women. This examination helps in developing strategies to increase men's participation in the prevention of violence against women. Examining how the men understand violence against women by men provides the opportunity to develop consciousness-raising strategies to raise men's comprehension about violence by men towards women and engage men 
who are concerned with the issues of violence against women by men. This provides possibilities to place greater emphasis on social change initiatives that incorporate principles of social justice by capitalizing on the well-meaning efforts of men who are concerned about violence against women by men.

The data from the research participants illustrates that they all understand that official statistics are only the tip of the iceberg of violence as social practices. This is not a surprising finding when considering the location of the men involved in this study. The majority of the research participants articulated an understanding that men, because of power and control, perpetuate violence against women. The Power and Control Wheel derives from an understanding that violence against women is founded upon the ideological framework of patriarchy, which as stated previously by Johnson, is "rooted in basically patriarchal ideas of male ownership of their female partners" $(2005$, p.284). In addition, the framework of the Power and Control Wheel rests not only upon the notion of classifying the behaviours of violent men on the personal levels, but also strives to educate men on the socio-political influences that perpetuate violence against women. As such, men who work with violent men, or who work in initiatives to increase men's participation to prevent violence in the lives of women, must understand the structural influences of violence.

The dialogue with the research participants with regards to violence against women, illustrates that they understand some aspects of the continuum as described by the Power and Control Wheel. The participants have a general understanding that violence takes different forms and that these behaviours 
derive from men who are striving to gain power over women. However, four participants discuss the violent behaviours and not the socio-political factors. The four participants only touch the surface of violence by discussing the individual behaviours of violent men without expanding to the socio-political understanding of the structural inequalities.

This is an important finding, especially when considering that all of the men are involved in different degrees in the prevention of violence committed by men towards women. One must examine the possible repercussions of engaging other men, when men who work in this field are not incorporating a structural or patriarchal analysis. As I will discuss in the following chapter, the repercussions can vary to some degree; however, a cornerstone belief for eliminating violence by men towards women must involve a well-informed analysis.

Although the majority of the men in this study are involved in the field of violence prevention, they all do not demonstrate a critical understanding of the socio-political structures with regards to violence. This illustrates that more work needs to be done with men who work with abusive men or who are involved in prevention efforts. Flood and Pease (2006) note that having an understanding of violence against women is imperative to change societal constructs of violence against women by men. Understanding the basic elements of what constitutes violence towards women by men helps in changing the attitudes of people. Therefore, a consciousness-raising strategy with men who are professionals and para-professionals in New Brunswick, working in this field, is needed to facilitate the process of raising their consciousness about the socio-political factors 
associated with violence. The successful implementation of consciousnessraising strategies with men who are allies with women can result in initiatives that challenge and attempt to change the structures within society that reinforce and support the oppressive elements that contribute to violence against women by men.

Men who are becoming allies in the struggle to eliminate violence against women, are a vital aspect in developing community mobilization initiatives to address this problematic. Therefore, an examination on how the research participants believe we can create processes that mobilize men to work together, with the goal to challenge the behaviours and structures associated with violence against women by men needs to be examined. The following chapter will take such examination and analyses the methodologies that men believe are necessary for engaging men. 


\section{CHAPTER FIVE}

\section{THE ENGAGEMENT OF MEN TO PREVENT VIOLENCE AGAINST WOMEN}

The following chapter examines the participants' dialogue on how we can engage more men in anti-violence prevention efforts that deal with violence against women by men. The previous two chapters delved more into the social constructions of masculinities and how men understand violence against women, which are vital aspects to developing strategies for engaging men to eliminate violence against women by men. The following chapter examines different frameworks that community workers can draw upon to create processes that engage men to end violence against women by men. This chapter begins by examining how men see their roles in these prevention efforts and discusses the contradictions associated with their participation. This chapter also discusses how the participants believe that prevention initiatives must examine the language associated with violence against women by men and anti-violence work. Some participants argue that the language discourse is an impediment that restricts men's participation. I will examine the opportunities and dangers that are associated with the belief that by transforming the language, and by being gender neutral, it will facilitate the mobilization of men to work on eliminating men's violence against women. I will also examine a constant theme throughout this thesis regarding how most men are unaware in acknowledging the structural aspects associated with violence against women. An important aspect in developing an authentic form of engagement is through the use of community development initiatives. This chapter further discusses the concept of 
consciousness raising, which is vital for community mobilizing strategies, especially in areas that involve creating community prevention efforts.

\section{Men's Role in Prevention Efforts to Eliminate Violence Against Women}

Men's participation in prevention efforts to eliminate violence against women is an important, but challenging concept for both women and men. The lack of involvement of men in anti-violence initiatives in the area of violence against women, derives not only from men who do not acknowledge or challenge their patriarchal privilege within society, but also from women who may be perplexed or fearful of men's involvement in anti-violence work. A complexity of issues involving men in prevention efforts to eliminate violence against women arises when they must work with women who have personally experienced violence by men. These women may be fearful or question the intentions of men who want or who are involved in anti-violence work. At other times, women's groups (and some men's groups) are perplexed because of historical and current men's initiatives that advocate the ideals of the patriarchal family structure and a strengthening of traditional roles between women and men in the public sphere. The rise of popular men's movements such as the Promise Keepers or the Mythopoetic men's movement are examples of groups that require caution because they argue the value in retaining strict gender divisions. At the core of these movements is the argument that men must return to stronger patriarchal family structures and reestablish a more traditional role of men and women within our society. Consequently, these men's movements do not challenge the 
oppressive social divisions within society, rather, they argue to strengthen the structural inequalities in society.

Due to the history of men's movements, feminist and pro-feminist groups are often apprehensive of men who want to be involved in the prevention of violence against women by men. Nevertheless, feminist and profeminist writers continue to believe and argue that men must become involved in the struggle to eliminate violence against women to change the oppressive social structures (hooks, 1984, 1994; Flood, 2004; Antrobus, 2004; and Bishop, 2002). For example, hooks states:

Women can no longer allow feminism to be another arena for the continued expression of antagonism between the sexes. The time has come for women active in the feminist movement to develop new strategies for including men in the struggle against sexism. (1984: p.72).

In a recent study, the World Health Organization (WHO) recommends an increase in men's participation in prevention efforts because they are viewed as playing a vital part in the prevention of violence against women (2005). Such recommendations and ideas are not new. Scholars, service providers, and activists have advocated for years that men have to play a greater role in the prevention of violence against women and children (see for example, hooks, 1984, 1994; Flood, 2004; and Antrobus, 2004).

All research participants in this thesis believe that men should collaborate with women on the issues of violence against women. When asked if they believe that men should work with women on the issue of violence against women, participant \# 1 explains, "people should work together. I think it is really a 
question of people who are concerned about these issues and feel passionate should be working together". Participant \# 4 provides his experience with a community initiative of men and women working together to end violence against women. He states "we are doing this with them. We share the resources [and are] trying to shore up the resources. It is power with, not power over" (Participant \# 4). The result of men working with women on the issue of violence against women provides the basis of building strong community responses. Participant \# 1 explains, "I see more power, it is more powerful working together" to end violence against women. An important concept of community development is bringing people together to work on specific issues of interest and this work involves processes which empower people within this community (Ife \& Tesoriero, 2006). Community development, according to Payne, "seeks to engage people with shared interests usually in a particular locality to come together, identify shared concerns and work jointly to overcome them" (2005, p.208). In the case of violence against women, Flood (2006) argues that men must develop community development initiatives and collective efforts if we want to prevent violence against women. Therefore, working as a community on specific goals provides the framework of working towards social change for the collective good.

Participants believe that building a healthy community that is free of violence is possible through social change. Shragge explains that one of the main beliefs of community development is mobilization, because "large numbers of people working together with specific demands can have a voice in the 
process of social change" (2003, p.137). Participant \# 7 explains this concept by saying, "when you change things for the better, it is for the whole community, it is not just for a relationship between me and my wife and me and my children. It is a change for the better, for the whole community, you know, a healthy community". Therefore, people must mobilize as a community and work for social change to end violence against women. This process, however, is more than having a leader who tells the community what needs to be done and then members follow this person without question. Rather, the sustainability of building a long lasting strategy of community engagement that involves all interested members must incorporate a sense of active participation. As Botes and Van Rensburg suggest, "development in the full sense of the word is not possible without appropriate community participation" (2000, p.56). Discussing the purpose of participation, Lee suggests that:

The point of participation, however, is not simply leadership. It is participation in action. Action has a positive effect on how we see ourselves; and how other people see us, and/or the issues for which we advocate. Problems are often ignored when we are not active in bringing them before the public. (1999, pp.44-45).

The participants illustrated that initiatives to end violence against women by men must derive from a community approach that brings people of both sexes together, rather than arguing for the separation of the two sexes in this struggle. The goal of bringing both sexes together provides the opportunity for creating prevention efforts to eliminate violence against women by men. 
The development of prevention initiatives regarding the issues of violence against women is an important mechanism to bring awareness into society (Crooks et al., 2007). In essence, the research participants in this study believe that more focus needs to be placed on the area of prevention. Participant \# 4 explains, "raising the awareness of what abuse is, is a kind of community consciousness". Furthermore, he states that this "creates an opportunity for dialogue, a conversation" and provides examples of initiatives that they undertook in their city by going "beyond the physical [and] they did numerous things [such as] radio, community posters, people could get them and put them in their office, they did billboards" (Participant \# 4). The purpose of this, according to Participant \# 4, is that "people saw these things, these posters and these words and so began the conversation". This illustrates a component of a group that is taking action on an issue. However, the challenge of these actions, although important, is that they are addressing the symptoms of violence and not challenging or changing the structural nature of violence in society. Even when participant \# 4 states, "prevention is more than education, we have to be aware, we have to understand, we have to know what we are wanting to prevent; you need to know all of that stuff". This participant discusses the personal components of violence against women and stresses that ending violence against women by men entails eliminating the behaviours of the men. However, participant \# 4 fails to address the structural aspects associated with the problem. In other words, he is not making the links between the personal and socio-political spheres of violence against women in our society. On the other 
hand, participants \# 1, 5, and 7 articulate an understanding that bridges the connections between the personal and social divisions in regards to issues of violence against women by men.

Participant \# 2 believes that we should use political leaders and other men who are respected male leaders in our community to promote a positive role model of men by having these male figures taking a stance against violence towards women by men. He states, "if you have lets say, a Wayne Gretzky or somebody like that, that is a symbol. [However, the] men must honestly talk about [violence against women], not only their three seconds slogan that you know is a marketing tool, but by being authentic, I think that has a major impact". However, he cautions us that this "is not easy because you need these role model to come to our level [because] that makes the connections".

Although the ideas and efforts of participant \# 2 of using men who are leaders in our communities to prevent violence against women by men does not address the root causes, these initiatives do play an important role. In fact, using respected male figures in the community to promote a stance that violence is wrong, and that it is beyond physical actions, and includes other behaviours are good beginnings to bringing greater awareness of violence in the communities. However, these initiatives do not go to the root causes of violence against women because the men are targeting the symptoms of violence rather than the root causes. Therefore, initiatives that use such an approach forgo any mechanism to attempt to link the violent behaviour against women by men to the socio-political divisions within society that are associated with violence against 
women. The language of violence against women was another component suggested by the research participants because they believe that the language associated with violence against women impedes the participation of men in their communities.

\section{Reframing the dialogue}

All research participants discuss the notions and importance of language and how it influences men in our society. As we have seen in Chapter three, Framing of Men and Masculinity, all men understand and argue that the notion of masculinity needs to change since the concept of masculinity portrays a distorted view of the identity of men. However, Participants \# 2, 3, 4, and 6 go further in their discussion about masculinity to include language. These men believe that we must begin to address and change the language associated with violence against women, because it restricts the ability to mobilize a greater number of men to work on this issue. This justification for reframing language regarding violence against women by men is explained by participant \# 3 when he explains his perception associated with this discourse. He states, "the feeling I get is that the men are the bad guys" (participant \# 3). This participant suggests that men are hostile or uninterested in this issue because the people who work in the area of violence against women portray that men are the 'bad guys'. Consequently, men are not getting involved in the discussion or prevention of violence against women committed by men. Changing the language to minimize the feelings of men as being portrayed as the 'bad guys' will increase the men's participation in anti-violence work that is perpetrated by men. 
The notion that the participants believe that the anti-violence movements are portraying men as the 'bad guys', illustrates a misrepresentation of a critical analysis because taking a socio-political analysis and challenging these social divisions does not suggest that men are 'bad guys'. Bishop (2002) explains that people who are viewed as the oppressors, but who are willing to become allies in the struggle for social justice, should recognize that they are not 'bad persons', rather, they need to acknowledge their privilege in society and work to change their behaviours and challenge these social divisions. Therefore, Bishop suggests that the oppressor groups who want to be allies in the struggle must learn to "separate guilt from responsibility. Guilt means taking on all the weight of history as an individual; responsibility means accepting your share of the challenge of changing the situation" (2002, p.115). Bishop believes that this process involves great humility by acknowledging that as men, you do not know how the oppression of women impacts someone. However, she reminds us that by the willingness of working as allies with an open mind and having the willingness to learn from the experience of others, the oppressors can be a valuable source of strength to make social change (Bishop, 2002).

The implications of not recognizing the socio-political constructs of violence against women by men, and its relationship with the personal spheres results in change that is superficial, rather than challenging the root causes of violence in our society. In other words, the changes are only addressing the symptoms of the problems. Therefore, Pease (2001) believes that men must do one of two things: either men accept the patriarchal constructs in society or else 
work as a community to challenge and change the oppressive divisions in society. The issue is how can we do this with men who do not acknowledge the socio-political constructs found within society.

The issue regarding men's lack of a socio-political analysis highlights the importance of having a dialectical process that begins with men's own lived reality, in which community workers bridge the structural divisions in society. This process would include community workers and men who are moving towards activism and who are willing to begin to challenge structural inequalities. It would include men who are willing to join women in the struggle to eliminate the structures that contribute to women's oppression, for example, joining women in the struggle and help advocate for pay equity where women are being paid less than men are for the same work. The role of the community workers must be to develop processes of critical consciousness-raising with men that will move them to action and ensure they participate in the struggle for social change and social justice.

Research suggests that to incorporate a process that provides the opportunity for active participation of men in anti-violence work, we must find "language, approaches and techniques that will actually reach and change the behaviours of boys and men" (Kaufman, 2001, p.11). Such an approach, argues Kaufman (2001), will result in men who will gain an increased sense of ownership regarding the issue of violence against women that is perpetrated by men. However, finding the language, approaches, and techniques does not suggest that we forgo the structural elements that support violence against women. Four 
of the seven participants' dialogue illustrates that their engagement strategies revolve around changing the language without acknowledging the structural constructions in regards to violence against women by men, such as promoting the idea of leadership to men as important qualities for developing healthy communities.

An approach that relinquishes the socio-political aspects of violence against women is suggested by participant \# 6 , who explains that we should talk about leadership with men because "there is one thing they have learned [and] that they are supposed to be leaders". He argues that when we are attempting to engage men around violence against women, we should approach the issue in terms of leadership. Participant \# 6 further adds, "when I mean leadership, the style that I am talking about is more collaborative leadership. So in a collaborative leadership there is a person who is taking responsibility to make sure that everybody is heard, that everybody needs [good] communication skills". He believes that changing the language associated with violence against women can be done through leadership. This means, men are leaders if they have good communication skills, good listening skills, are respectable with people of both genders, and work in a collaborative manner with groups of people. This approach is an important concept in redefining leadership that is not based from the capitalistic ideals of competition and power over; however, such a strategy focuses only on the personal behaviours of the individuals, and there is no linking of these behaviours with the structural elements found in our society. 
The well-meaning intentions of these participants must be acknowledged because they are trying to work on prevention initiatives to stop violence against women. It is important to remember that acknowledging these good intentions by feminist and profeminist is vital in engaging more men (Crooks, Goodall, Hughes, Jaffe, and Baker, 2007). However, the implications of changing the language to accommodate men's feelings does not take into consideration the socio-political structures associated with violence against women by men. Rather, changing the language and not discussing patriarchy and other socio-political social divisions, is another illustration on how men are privileged with such accommodations within the patriarchal and capitalistic society. Does this then imply that we cannot accommodate men in a group setting with their own reality and understanding on the issue of violence against women? To answer this dilemma, community workers may find part of the solution within a community development approach that uses the concept of consciousness-raising and that enables people to make the connections between the personal and socio-political spheres. The goal of such an approach would be to empower individuals to take collective action and address the social divisions within society.

\section{Consciousness-Raising and Violence Against Women By Men}

Community development initiatives that involve consciousness-raising methodologies are important to increase community participation. Ife and Tesoriero explain that this "can simply be a way of working that seeks any opportunity to engage in dialogue and to explore paths towards collective understanding, shared experience and action" (2006, p.179). In the case of 
violence against women by men, Kaufman (2001) suggests that a process which involves authentic and active forms of participation from men to prevent violence against women, creates an increased sense of ownership in the issue. As such, authentic male participation creates a framework for men to move towards a profeminist analysis in their work to end violence perpetrated by men. The participation of men to become allies in prevention efforts to end violence against women in their communities is facilitated through consciousness-raising efforts. As seen previously, all participants believe that it is possible to eliminate violence against women by men by building strong and healthy communities.

Ife and Tesoriero (2006, pp.176-178) explain that there are four aspects of consciousness-raising. The first is "linking the personal and the political"; second, "the establishment of a dialogical relationship"; third, "sharing experiences of oppression"; and fourth, "should open up possibilities for action". The first process of consciousness-raising derives from the feminist concept of bringing personal situations and linking these experiences to the political structures within society. Participant \# 1 suggests the importance of having a discussion among people regarding the personal and political experiences of violence against women in society. He states, we must "bring the dialogue, not necessarily education, [since] I do not necessarily have the answers, but making sure [violence against women] is being discussed" (Participant \# 1). Furthermore, participant \# 1 infers that through a process of dialogue on the issue of violence against women, groups can begin to develop a greater critical understanding of the root causes of violence. Therefore, facilitating processes which allow 
individuals to make the connections between the personal and political spheres is vital to building any consciousness-raising initiative.

The role of community workers is imperative in facilitating the process of linking the personal and political sphere together. As Ife and Tesoriero state, "a community worker can do this effectively only if she/he has an awareness of the connection, and understands the way in which dominant structures and discourses of power deny the connection and make it difficult for people to make the link" (2006, p.176). Therefore, since four of seven male participants do not make the connections between the personal and political spheres, it is imperative that we address this issue if the goal is striving for a transformation of the oppressive structures that contributes to violence against women by men.

The second aspect of Ife and Tesoriero (2006) is establishing a dialogical relationship. As Paulo Freire explains, "often, educators and politicians speak and are not understood because their language is not attuned to the concrete situation of the people they address. Accordingly, their talk is just alienated and alienating rhetoric" (2003, p.96). Similarly, Freire argues, "that investigation must likewise be dialogical, affording the opportunity both to discover generative themes and to stimulate people's awareness in regard to these themes" (2003, pp.96-97). This "requires that the community worker not enter into the relationship claiming to be the expert with superior knowledge, but instead adopts the position of valuing local knowledge, and seeking an equal dialogue with community members where each can learn from the other, so that they can together move towards collective action" (Ife and Tesoriero, 2006, p.177). An 
important concept of community development is working at the grassroots. The processes of dialogical relationship are of vital importance when working at the grassroots because the community worker is working with people who are concerned and knowledgeable about specific issues in their community. Participant \# 5 explains that prevention efforts need to "start from the bottom up", in other words, reaching to people from the grassroots. Furthermore, he explains that "we've got to start with ordinary people and listen to what they are saying and not pay as much attention, or let's try and not pay as much attention to the expertise coming from the top down" (Participant \# 5). Hence, he is arguing that community workers need to work with people with the goal to develop a dialogical relationship. If the community worker is informed from a structural understanding of society, this in turn will help the group of people to identify and name their own experiences and through facilitation, the community worker can help in moving the group to make the connections between the personal and socio-political spheres.

The third aspect of Ife and Tesoriero (2006) consciousness-raising model is sharing the experiences of oppression, which illustrates the importance of having authentic discussions among a group of people in sharing their own experiences of oppression. However, this is problematic with men who want to end violence against women because of the patriarchal frameworks within society. In regards to this study, it is even more challenging when only three of the seven participants made references, or implied in their discussion, the notion of patriarchy. Pease (1999) describes this problematic by explaining that "men in 
general are advantaged through the subordination of women, although ethnographically speaking, different men are advantaged in different ways" (p.101); which is paradoxical to the notion of progressive social movements, since the life cycle of progressive social movements has its roots in challenging oppressive injustice. Consequently, this results in men movements that are no longer focused on the issues of social justice and social change.

Most people in society do face one or more form of oppression, whether it is because of class, gender, race, sexuality, disability, age, language, or privilege. Therefore, a process of working with a group of men and women must entail this sharing, but it is vital that a community worker is informed of the sociopolitical structures of violence against women by men. A community worker facilitating processes to engage men, can help the group to make the connections between the personal and the socio-political spheres around violence against women by men and their own experience of oppression, such as classism or racism. With such an approach, there is the possibility that these men's consciousness will increase around the structural elements associated with violence and, they can begin the processes necessary to become mobilized in social justice initiatives to challenge the socio-political barriers that is associated with violence against women.

The fourth aspect suggested by Ife and Tesoriero (2006) of consciousness-raising is opening up the possibilities of action. This is a fundamental concept for consciousness-raising because it provides the opportunity for the community to work towards social change. Although 
participant \# 1 states that he is "still trying to establish what role I can play", through his involvement with his fellow activists, he was able to take action to raise awareness in the general public. For example, participant \# 1 explains that he helped in "organizing movie nights and help[ed] write articles for the newspapers about the issues". The purpose of such action according to Participant \# 1 is to promote the idea "to other men that it is not women against men, [rather] it is a human issue, it is a problem. Women are the victims in this case and we need to address this directly". Therefore, this process provides the occasion to demonstrate to men that they can and must become involved in antiviolence work. This example by participant \# 1 illustrates pro-active initiatives that men can take to eliminate violence against women.

The goal of pro-active initiatives which involve men is important for two significant reasons. First, men's activism "symbolizes the growing recognition that violence against women will only cease when men join with women to put an end to it" (Flood, 2001, p.44). Flood (2001) further notes that recognizing the importance of men to be involved in prevention efforts to stop violence against women are being institutionalized through diverse programs and philosophies. The second significance of men's pro-active initiatives according to Flood (2001), is that the "existence of men's anti-violence activism demonstrates that men can take collective public action to oppose men's violence" (p.44). Nevertheless, this process must involve a framework of authentic participation rather than a methodology of speaking to the men (Flood, 2001). In other words, this involves having a dialogical relationship which will help to move the men towards activism 
with the goal of stopping and eliminating violence towards women by men. Community workers and men must locate and challenge the structural divisions in society that reinforce and oppress women in our society. Only then can men move towards activism and challenge the structural elements, for example, that support paying women lower wages when compared to men who do the same work; or the notion that devalues the unpaid labour of women who work at home.

\section{Conclusion}

This chapter examined several important concepts on how the research participants believe we as a community can involve the participation of men in eliminating violence against women by men. The chapter illustrates that all of the research participants believe that men and women should be working together in prevention efforts of violence against women. In addition, all of the participants believed that a community approach is necessary to eliminate violence against women by men. The participants provided some examples of prevention efforts that they are doing in their community such as, developing posters, radio ads, and other social marketing tools to bring awareness of violence against women to the public. However, as we have seen, these initiatives, although well intentioned in educating the public and trying to break the notions that violence against women is only physical, are only touching the surface of violence by explaining the behaviours of violence. The initiatives do not help to make the connections between the personal and socio-political spheres. Furthermore, some participants believe that the prevention efforts to stop violence should use male authority figures to promote a message of healthy relationships. However, 
the challenge of these sorts of public education campaigns is that they do not facilitate processes of engagement among other men to take a leadership role in prevention and to start working to eliminate violence in communities.

A constant theme throughout this chapter, including the rest of this study is that the majority of the participants, such as, participants \# $2,3,4$, and 6 do not make the connections between the personal and socio-political spheres regarding violence against women. Rather, these participants provide arguments that only focus on the surface of issues and the problems and do not tap into the root causes, although, there is informative knowledge that can be gained by examining their ideas on engaging men.

Participants \# 2, 3, 4, and 6 argue that more emphasis is needed on reframing the dialogue that is associated with violence against women. As we have seen, the perception of discussing violence against women is viewed as being anti-male, thus, the participants argue that if we change the dialogue around violence, we can begin the process of developing a framework to engage more men in anti-violence work. However, there are dangers in reframing the dialogue of violence against women because as we can see from participants \# $2,3,4$, and 6 , they are not informed from a critical analysis that bridges the personal and socio-political structures together, even if they are already involved within this field of practice. Therefore, not addressing the personal and structural spheres, results in engagement strategies that are not addressing the root causes and working toward social change and social justice. One example of an engagement strategy is reframing the concept of leadership. Participant \# 6 
argued that the community needs to change the language by using the concept of collaborative leadership. Therefore, he believes by working with men to teach them other leadership styles, such as a style of leadership that is based on respect and communication among people, men will be more open to work on building healthier relationships. However, this concept does not facilitate an understanding of the socio-political constructs of violence against women by men and as such, does not challenge the social construction of violence within society. Rather, it focuses on the behaviours without providing the necessary tools to bridge the connections between the personal and political spheres with men, which is vital to eliminate violence against women that is perpetrated by men.

The importance of developing a critical understanding of violence against women is imperative to develop strategies of consciousness-raising. Participants $\# 1,5$, and 7 provided a critical understanding of engaging men that are informed, in part, with the concepts of consciousness-raising. Ife and Tesoriero (2006) provided four steps to the consciousness-raising, which are: linking the personal and the political; the establishment of a dialogical relationship; sharing experiences of oppression; and open up possibilities for action. Participants \# 1, 5 , and 7 provided an analysis that incorporated three of the four aspects as suggest by Ife and Tesoriero (2006) in consciousness-raising. These participants discussed the importance of linking the personal and political, the establishment of a dialogical relationship, and the opening the possibilities for action on the issues of violence against women. Nonetheless, an important, but controversial 
element is in the third stage of Ife and Tesoriero's (2006) model for consciousness-raising, which is the sharing of experiences of oppression. This is even more difficult for men because of the patriarchal structures within society, which privileges men over women. It is important to acknowledge that not all men are equal within society, whether it is based on divergent masculinities, such as homosexuality, class, and/or race among other forms of oppression. Therefore, there is the possibility that by working with women and men together, the experiences of oppression can be shared among each other. If the men have humility, as suggested by Bishop (2002), they can have an open dialogue among both women and men in making the connections between the oppressive social divisions, especially when classism, racism, sexism, ageism, heterosexism and all the other isms are all interconnected together. Therefore, an approach that incorporates the different structural elements of oppression by a community worker can facilitate the process of consciousness-raising and open-up possibilities for social change on the issue of violence against women. Furthermore, community workers, through a process of consciousness-raising, can facilitate the men to move towards activism to challenge the structural divisions in society, such as challenging the criminal justice system which do not recognize and address adequately the severity of violence against women by men. Men can also begin to challenge all level of government and demand that shelters for women who are abused are adequately funded, and provide their senvices in their communities. Therefore, this consciousness-raising process can increase men's understanding of bridging the personal and socio-political 
spheres and move the men to take actions to change the oppressive elements in society.

Prevention efforts striving to engage men must take on initiatives that will acknowledge the well meaning ideas and efforts of men who may not have an analysis that fully follows the profeminist and feminist ideals regarding violence against women by men. This acknowledgement provides the opportunity for raising the consciousness of men about their values and beliefs regarding violence against women. Raising men's level of consciousness has the potential of changing their pre-conceived understanding of violence against women and to move them towards a critical analysis that will inform their actions for social change. As Pease suggests, "I believe that men can change in the direction of feminism. Men have choices as to whether they accept patriarchy or work collectively against it. Before men can organize collectively, though, they must transform their subjectivities and practices" $(2001$, p.3). Therefore, it is imperative that profeminist men and feminist women become more open minded and acknowledge the well meaning men by providing space for these potential allies to grow in their feminist understandings and analyses. 


\section{CHAPTER SIX}

\section{CONCLUSION}

The following study examines processes that male key informant research participants believe are important to increasing men's participation in prevention efforts to eliminate violence against women by men. This chapter provides a discussion of the themes that emerged from this research to the research question: "what are the perspectives that can increase men's participation in the prevention of violence against women in New Brunswick's local communities?" This chapter examines the three chapters of the thesis and bring the themes together and provide the opportunity for reflecting on the strengths and gaps of the themes in order to provide an understanding and possible direction towards developing processes that engage more men in prevention initiatives with the goal of eliminating violence against women by men.

There are several interesting themes throughout this study and I believe are important to re-examine, especially when we want to develop community initiatives to eliminate violence against women by men by using strategies that address the structural context of the issue. The chapter, Framing of Men and Masculinity, examines the research participants' understanding of masculinity. The men's understanding of masculinity was an interesting finding because the men argued that the social constructions of masculinity must be addressed if we want to engage more men towards the prevention of violence against women by men. All the men explained that the constructs of masculinities are not realistic descriptions of the male experience. Although there was some discrepancy 
among the research participants' understanding of masculinity; all men argue the importance of challenging the social constructions of masculinity. The participants illustrate that the process of challenging the constructions of masculinity has the potential for social change, and consequently has the potential to eliminate violence against women by men. Although the majority of the research participants did not connect the personal sphere with the sociopolitical context associated with the constructions of masculinity, I illustrated that six of the seven men identified the symptoms of hegemonic masculinity. Nevertheless, I showed that only three of the seven men provided a critical understanding of masculinity associated with the framework of hegemonic masculinity. This is important when considering that all of the research participants are involved in either (or both) counseling with men who are abusive towards women, or the prevention of violence against women in their communities in different capacities. Therefore, this finding suggests that more research is required that examines men who are involved in this field of inquiry. The importance of acknowledging the good intention of these men is vital if community workers want to develop initiatives in their communities that challenge both the personal and socio-political context associated with violence against women by men. As such, we cannot dismiss these men in the struggle to end violence against women by men, rather, community workers must build on the good intentions of men and develop consciousness-raising methodologies that will raise the critical consciousness of these men by bridging the personal and socio-political context associated with violence. Such a methodology can spur 
the development of strong and committed allies who will struggle in solidarity with the other men, women's groups, and/or organizations towards the elimination of violence against women by men.

Chapter four, Men's Understanding of Violence Against Women, examined how my research participants understand violence against women by men. The discussion by the participants regarding the prevalence of male violence against women indicated that they had a well-rounded understanding of the official statistics associated with violence against women by men. The research participants further demonstrated that violence against women is more than the realm of physical violence and includes, among others, the emotional and economical aspect of violence. The chapter also demonstrated that all men believe it is imperative to have an understanding of violence against women for engaging men in the prevention of violence against women by men. The majority of men demonstrated that they understand violence against women by men as deriving from the symptoms associated with the concepts with the Power and Control Wheel.

The majority of my research participants demonstrated that they lack an understanding of the structural context that is associated with violence against women. Only three of the seven men involved in this study highlight a critical understanding and make a connection between the personal and socio-political spheres of violence against women in our Western society. The finding illustrates that most men, although they may believe they have a critical understanding of violence against women, only name the symptoms of violence against women 
without bridging the personal and structural contexts. Although they demonstrated an understanding of the symptoms of the Power and Control Wheel, only three of the seven participants grasped the socio-political milieu within their discussions. Four of the seven men articulated an understanding that names the symptoms of the problem and only names the behaviour and tactics of abusive men towards women. This finding is significant because all of my research participants are involved in different capacities within this field of inquiry. Although these findings cannot be generalized because of the nature of this study, I believe that more research is required to critically examine the training and education that men who work in this field are receiving. One hypothesis of such an inquiry is that the researchers may find gaps within the training of the men (if they received any) who are working in this field. I believe it is important to ask the question, whether men who work in this field have an understanding of violence against women by men that involves a critical examination of the issues that links the personal and socio-political contexts, and how these men can authentically develop processes that focuses on the elimination of violence in our society at both the structural and personal levels. I believe that it is imperative that men who work in this field work with the intention of eliminating violence against women by men, not only at the personal level, but by changing the structured divisions in society that contributes and reinforces violence against women by men.

In chapter five, The Engagement of Men to Prevent Violence Against Women, I discussed how the research participants believe they can increase the 
participation of men in prevention efforts to eliminate violence against women. All men believed in the importance of working with women groups. This process of working with women on this issue, according to the participants, is because it provides more power in addressing violence by men towards women. All men believe that a community approach is one of the best methods to develop processes of engaging men in the struggle to end violence against women by men. Although they all believe in working with women's groups and working at the community level, this study illustrates that four of the seven participants do not have a structural understanding of violence against women by men. Rather, they articulated an understanding that to engage more men, we need to develop a greater awareness that demonstrates and makes clear to other men in our communities that using violence towards women is wrong.

The issue of language was highlighted as an impediment to men's participation because the language of violence against women feels as if it is anti-male. Four of the seven participants argue that we need to develop language that is more inviting for men. An example of reframing language is by using common concepts, such as leadership. Therefore, community workers should strive to use words that are common with men and to reframe the dialogue associated with the concept. As such, community workers should strive to change the concept of leadership and link it to men who are involved in work to eliminate violence against women by men. Although this idea is well-intentioned, this approach does not raise the men's critical understanding of violence against women by men and does not challenge the structural context. 
Three of the seven men provided an understanding that derives from processes of consciousness-raising. To assess the men's understandings and methods of consciousness-raising, I used the framework developed by Ife and Tessoriero (2006). Using this framework helped in assessing the gaps within their understanding to identify possible areas that can be incorporated in the consciousness-raising processes with the goal of increasing the participation of other men in the efforts to eliminate violence. They highlighted the importance of linking the personal and political, the establishment of a dialogical relationship, and the opening of possibilities for action on the issues of violence against women. However, an important element of consciousness-raising is sharing the experiences of oppression. This process is controversial with men because men have the inherent privileges associated with patriarchy in our Western society. Nonetheless, I do believe there is room to maneuver in this stage. Structural social work acknowledges different forms of oppression, such as classism, racism, heterosexism and onwards. Furthermore, a community worker who has a structural analysis of society can help to facilitate the interconnectedness of oppressions in consciousness-raising efforts. As such, this stage provides the opportunity for men to examine their own experiences of oppression and empower them toward starting the process for taking social change actions towards the principles of social justice. The community worker can thus help move the men towards a pro-feminist perspective of violence against women by men. 


\section{Bringing the Pieces Together}

The challenges associated with this study were to bring the different themes associated with the male participants to answer the main research question: "what are the perspectives that can increase men's participation in the prevention of violence against women in New Brunswick's local communities?" A significant finding of this study is that throughout the chapters, four of the seven male participants do not make the connections between the personal spheres and the structural context associated with violence against women. Therefore, the process of engaging more men in the prevention of violence against women needs to be reexamined by both feminist and pro-feminist writers. I believe that this study illustrates, or at the very least, provides a basis for the argument that we need to begin, as a first step, working with men who work in this area. There needs to be a process of consciousness-raising that provides the male workers in this field to develop their critical consciousness regarding violence against women by men. However, this will entail a great deal of humility among men because the male para-professionals and professionals will need to reexamine their own practice and reflect on their values and beliefs. Nonetheless, this is imperative if we want to develop engagement strategies of men to prevent and eliminate violence against women. This is one method to increase awareness of men who work in this field of the structural context that is associated with violence against women. Community workers can increase men's critical consciousness by providing concrete examples of structural elements that disadvantage women, such as the lack of funding to women's shelters because 
governments' policies do not adequately provide sufficient financial resources to meet the needs of women who need the service. This method, I maintain can provide the basis for developing the men's participation to eliminate violence against women by men, and deals not only with the personal spheres, but also with the structural elements of oppression.

Another dimension to working with men with the goal of developing engagement strategies that will involved authentic forms of participation, is by acknowledging the oppressive factors within society that affect men. It is documented that sexism and other forms of oppression also affect the lives of men in negative ways (Pease, 2001). However, community workers can use this oppressive form of impediment to men's lives and transform these experiences towards anti-sexist initiatives that seek to change and challenge these social constructions. Schapiro (2001) explains that "through a process of dialogue, problem-posing, and action, Freirian education presents men with the opportunity to make connections between the limitations of traditional gender roles and patriarchal institutions and power relations in which those roles are embedded" (p.2). As such, Schapiro (2001) explains:

Those limits that men experience through the constraint of the traditional male gender role can be traced directly to sexism and women's oppression, and as Freire (1970) himself pointed out, there is the dehumanization which all oppressors experience when they are in dominant/subordinate relationships and treat others in dehumanizing ways (2001, pp. 5$6)$.

This study has discussed how the men viewed masculinity and how it derives from the concepts of hegemonic masculinity, which portrays illusions of 
the masculine self. Therefore, one of the goals that community workers who attempt to increase men's participation to eliminate violence against women by men in our communities can take these illusionary forces that defines masculinities in our society and use these influences to develop men's critical consciousness. This provides the opportunity to community workers who are developing critical consciousness about masculinity with men, to facilitate the socio-political connections associated with violence against women by men. However, more research is needed that attempts to understand in detail how we can use the concepts of hegemonic masculinity, which supports and reinforces unrealistic masculine ideals and behaviours with men, within pro-feminist analyses. Therefore, I recommend that researchers in this field of inquiry examine the impact of hegemonic masculinity on men and develop pedagogies to attempt to link these illusions with socio-political understanding with the goal to develop a framework in order to work with men in our communities.

I believe this study provided an understanding of how we can begin to increase men's participation in our communities to eliminate violence against women by men. The goal of increasing men's participation is a complex phenomenon and at times can be a dangerous endeavor if community workers do not have a critical understanding of violence against women by men, because it can recreate and reinforce the oppressive structures in our society. However, 1 believe that working on these issues is also full of opportunity and possibility to create healthier and safer communities for everyone. I believe that the end goal of social justice cannot succeed without the elimination of violence against 
women by men, and I believe it is only by involving men in this social change struggle that we, collectively, can succeed. I hope that this study will help in continuing the dialogue and showing the importance of involving men in the struggle to eliminate violence against women by men in our communities. I also hope that this study contributed to the literature on how we can develop processes to increase men's participation for the elimination of violence against women by men in our communities. 


\section{REFERENCES}

Adamson, N., Briskin, L., \& McPhail, M. (1988). Feminist Organizing for Change: The Contemporary Women's Movement in Canada. Toronto: Oxford University Press.

Bishop, A. (2002). Becoming an Ally: Breaking the Cycle of Oppression in People $\left(2^{\text {nd }}\right.$ ed.). Halifax: Fernwood Publishing.

Botes, L., \& Van Rensburg, D. (2000). Community Participation in Development: Nine Plagues and Twelve Commandments. Community Development Journal, 35(1), 41-58.

Boylatis, R. (1998). Transforming Qualitative Information: Thematic Analysis and Code Development ( $2^{\text {nd }}$ ed.). Thousand Oaks: Sage.

Braun, V., \& Vlarke, V. (2006). Using Thematic Analysis in Psychology. Qualitative Research in Psychology, 3, 77-101.

Butler, J. (1990). Gender Trouble: Feminism and the Subversion of Identity (2 $2^{\text {nd }}$ ed.). New York: Routledge.

Carniol, B. (1995). Case Critical: Challenging Social Services in Canada ( $3^{\text {rd }}$ ed.). Toronto: Between the Lines.

. (2005). Analysis of Social Location and Change: Practice Implications. In S. Hick, J. Fook, \& R. Pozzuto (Eds.). Social Work: A Critical Turn (pp.153-165). Toronto: Thompson Educational Publishing.

Connell, R.W. (1995). Masculinities. Berkeley and Los Angeles: University of California Press.

Gardnier, J.K. (2005). Men, Masculinity, and Feminist Theory. In M. Kimmel, J. Hearn, \& R.W. Connell (Eds.). Handbook of Studies on Men and Masculinities (pp.35-50). Thousand Oaks: SAGE Publication.

Capraro, R. (1994). Disconnected Lives: Men, Maculinity, and Rape Prevention. In A. Berkowitz (Ed.). Men and Rape: Theory, Research, and Prevention Programs in Higher Education. San Francisco: Jossey-Bass Publishers.

Crooks, C., Goodall, G., Hughes, R., Jaffe, P., \& Baker, L. (2007). Engaging Men and Boys in Preventing Violence Against Women: Applying a CognitiveBehavioral Model. Violence Against Women, 13(3), 217-239. 
Dankwort, J. \& Rausch, R. (2002). Men at Work to End Wife Abuse in Quebec: A Case Study in Claims-Making. In K. McKenna, \& J. Larkin (Eds.). Violence Against Women: New Canadian Perspectives (pp.423-440). Toronto: Inanna Publications and Education Inc.

Desekeredy, W., Schwartz, M., \& Alvi, S. (2000). The Role of Profeminist Men in Dealing with Woman Abuse on the Canadian College Campus. Violence Against Women. 6(9), 918-935.

DeKeseredy, W., \& Schwartz, M. (2002). The Incidence and Prevalence of Woman Abuse in Canadian Courtship. In K. McKenna \& J. Larkin (Eds.), Violence Against Women: New Canadian Perspectives (pp.93-122). Toronto: Inanna Publications and Education Inc.

Dominelli, L. (2003). Working with Men from a Feminist Perspective. In J. Wild (Ed.), Working with Men for Change (pp.17-38). London: Routledge.

Flax, J. (1990). Postmodernism and Gender Relations in Feminist Theory. In L. Nicholson (Ed.). Feminism/Postmodernism (pp.39-62). New York: Routlegde.

Flood, M. (2001). Men's Collective Anti-Violence Activism and the Struggle for Gender Justice. Development, 44(3), 42-47. (2002-2003). Engaging Men: Strategies and Dilemmas in Violence Prevention Education Among Men. Women Against Violence, 13, 25-32. . (2006). Changing Men: Best Practice in Sexual Violence Education. Women Against Violence, 18, 26-36.

Flood, M., \& Pease, B. (2006). The Factors Influencing Community Attitudes in Relation to Violence Against Women: A Critical Review of the Literature. Available Online: http://www.vichealth.vic.gov.au/assets/contentsFiles/CAS Paper3 CriticalLiterature.pdf.

Foucault, M. (1980). Power/Knowledge: Selected Interviews and Other Writings 1972-1977. New York: Pantheon. (1984). The Foucault Reader. New York: Pantheon.

Freire, P. (1970). Pedagogy of the Oppressed. New York: Continuum International Publishing Group Inc.

. (2000). Pedagogy of the Oppressed $-30^{\text {th }}$ Anniversary Edition. New York: Continuum International Publishing Group Inc. 
Gilroy, J. (1990). Social Work and the Women's Movement. In B. Wharf (Ed.). Social Work and Social Change in Canada (pp.52-78). Toronto: McClelland \& Stewart Inc.

Gramsci, A. (1971). Selections from the Prison Notebooks. New York: International Publishers.

Haj-Yahia, M. (2003). Beliefs About Wife Beating Among Arab Men from Israel: The Influence of Their Patriarchal Ideology. Journal of Family Violence, (18)4,193-206.

Harding, S. (1990). Feminism, Science, and the Anti-Enlightenment Critiques. In L. Nicholson (Ed.). Feminism/Postmodernism (pp. 83-106). New York: Routledge.

Hearn, J. (2001). The Violences of Men: How Men Talk About and How Agencies Respond to Men's Violence to Women. London: Sage Publications.

hooks, b. (1984). Feminist Theory: From Margin to Center. Boston: South End Press.

(1990). Yearning: Race, Gender, and Cultural Politics. Toronto: Between the Lines.

. (1994). Teaching to Transgress: Education as the Practice of Freedom. New York: Routledge.

. (2000). Feminism Is For Everybody: Passionate Politics. Cambridge: South End Press.

Hornosty, J., \& Doherty, D. (2003). Responding to Wife Abuse in Farm and Rural Communities: Searching for Solutions that Work. In R. Blake \& A. Nurse (Eds.), The Trajectories of Rural Life: New Perspectives on Rural Canada (pp.37-53). Regina: Saskatchewan Institute of Public Policy.

Hong, L. (1999). Redefining Babes, Booze and Brawls: Men Against Violence Towards a New Masculinity. USA: Dissertation.com . (2000). Towards a Transformed Approach to Prevention: Breaking the Link Between Masculinity and Violence. Journal of American College Health, 48, 269-279.

Ife, J., \& Tesoriero, F. (2006). Community Development: Community-Based Alternatives in an Age of Globalisation ( $3^{\text {rd }}$ ed.). French Forest: Pearson 
Jaggar, A. (1983). Feminist Politics and Human Nature. Toronto: Rowman \& Littlefield Publishers.

Jiwani, Y. (2002). The 1999 General Social Survey on Spousal Violence: An Analysis. In K. McKenna and J. Larkin (Eds.), Violence Against Women: New Canadian Perspectives. (pp.63-72). Toronto: Inanna Publications and Education Inc.

Johnson, A. (2005). The Gender Knot: Unraveling Our Patriarchal Legacy. Philadelphia: Temple University Press.

Johnson, H. (2002). Methods of Measurement. In K. McKenna \& J. Larkin (Eds.), Violence Against Women: New Canadian Perspectives (pp.21-54), Toronto: Inanna Publications and Education Inc.

Johnson, M. (1995). Patriarchal Terrorism and Common Couple Violence: Two Forms of Violence Against Women. Journal of Marriage and the Family, 57, 283-294.

Katz, J. (1995). Reconstructing Masculinity in the Locker Room: The Mentors in Violence Prevention Project. Harvard Educational Review, 65(2). Online: http://www.edreview.org.proxy.hil.unb.ca/havard95/1995/su95/s95katz.ht m.

Kaufman, M. (1993). Cracking the Armour: Power, Pain and the Lives of Men. Toronto: Penguin Books Canada. . (2001). Building a Movement of Men Working to End Violence Against Women. Development. 44(3), 9-14.

Kimmel, M. (2005). The History of Men: Essays on the History of American and British Masculinities. Albany: State University of New York Press.

Kirby, S., \& McKenna, K. (1989). Experience, Research, Social Change: Methods From the Margins. Toronto: Garamond Press.

Kivel, P. (1992). Men's Work: How to Stop the Violence That Tears Our Lives Apart. Minnesota: Halzelden.

Lecomte, R. (1990). Connecting Private Troubles and Public Issues in Social Work Education. In B. Wharf (Ed.). Social Work and Social Change in Canada (pp.31-51). Toronto: McClelland \& Stewart Inc.

Lee, B. (1999). Pragmatics of Community Organization ( $3^{\text {rd }}$ ed.). Mississauga: CommonAct Press. 
Lerner, G. (1986). The Creation of Patriarchy. New York: Oxford University Press.

Lundy, C. (2004). Social Work and Social Justice: A Structural Approach to Practice. Peterborough: Broadview Press.

Malhstedt, D. \& Welsh, L. (2003). Perceived Causes of Physical Assault in Heterosexual Dating Relationships. Violence Against Women, 11(4), 447472.

Marlow, C. (2005). Research Methods for Generalist Social Work ( $4^{\text {th }}$ ed.). Toronto: Thomson and Brooks/Cole.

Moreau, M. (1979). A Structural Approach to Social Work Practice. Canadian Journal of Social Work Education, 5(1), 78-94.

Mullaly, B. (1997). Structural Social Work: Ideology, Theory, and Practice (2 ${ }^{\text {nd }}$ ed.). Don Mills: Oxford University Press. (2002). Challenging Oppression: A Critical Social Work Approach. Don Mills: Oxford University Press.

(2007). The New Structural Social Work ( $3^{\text {rd }}$ ed.). Don Mills: Oxford University Press.

Naples, N. (1998). Community Activism and Feminist Politics: Organizing Across Race, Class, and Gender. (Ed.). New York: Routledge.

NBACSW. (2006). 2006 Report Card on the Status of Women in New Brunswick: A Statistical Profile. Fredericton: Province of New Brunswick.

Orme, J., Dominelli, L., and Mullender, A. (2000). Working with Violent Men from a Feminist Social Work Perspective. International Social Work. 43(1), 89105.

Paymar, M. (2000). Violent No More: Helping Men End Domestic Abuse ( $2^{\text {nd }}$ ed.). Alameda: Hunter House Publishers.

Payne, M. (2005). Modern Social Work Theory ( $3^{\text {rd }}$ ed.). Chicago: Lyceum Books.

Pease, B. (2001). Developing Profeminist Practice with Men in Social Work. Critical Social Work, 2(1). 1-7. Available Online: http://criticalsocialwork.com/units/socialwork/critical.nst/printerFriendlyVie w/922C4C37984F3C6D85256EA800654BCS 
. (2002). (Re)constructing Men's Interests. Men and Masculinities, 5, 165177.

Pence, E. (2005). Batterer Programs: Shifting from Community Collusion to Community Confrontation. In R. Berres (Ed), Violence Against Women (pp.368-390) Boston: Person Education.

Pence, E., \& Paymar, M. (1986). Power and Control: Tactics of Men Who Batter. Duluth: Minnesota Program Development.

Pence, E., \& Sheppard, M. (1999). An Introduction: Developing a Coordinated Community Response. In E. Pence \& M. Sheppard (Eds.), Coordinating Community Responses to Domestic Violence: Lessons from Duluth and Beyond (pp.3-24). Thousand Oaks: Sage.

Reinharz, S. (1992). Feminist Methods in Social Research. New York: Oxford University Press.

Renzetti, C. M. (1999). Editor's Introduction. Violence Against Women, 5, 12351237.

Russell, S. (1996). Take Action for Equality, Development and Peace: A Canadian Follow-up Guide to Beijing '95. Ontario: Canadian Beijing Facilitation Committee.

Schapiro, S. (2001, July). A Freirian Approach to Anti-Sexist Education With Men: Toward a Pedagogy of the "Oppressor". Proceedings Fielding Graduate Institute Action Research Symposium. Alexandria, VA.

Seidler, V. J. (1999). Men, Power, Control, And Violence. In J. Wild (Ed.), Working With Men For Change (pp.181-196). New York: Routledge.

Shragge, E. (2003). Activism and Social Change: Lessons for Community and Local Organizing. Peterborough

Statistics Canada. (1993). The Violence Against Women Survey. Ontario: Statistics Canada.

Thompson, N. (1997). Anti-Discriminatory Practice (2 ${ }^{\text {nd }}$ ed.). London: Macmillan.

Thoreau, D. (2004). Walden and Other Writings. New York: Bantam Books.

Van den Hoonaard, W. (2002). Walking the Tightrope: Ethical Issues for Qualitative Researchers. Toronto: University of Toronto Press Inc. 
Vickers, J. (2002). Thinking About Violence. In V. Dhruvarajan \& J. Vickers (Eds.), Gender, Race, and Nation: A Global Perspective (pp.222-246). Toronto: University of Toronto Press.

Weedon, C. (1999). Feminism, Theory and the Politics of Difference. Massachusetts: Blackwell Publishers.

Weinberg, M. (2008). Structural Social Work: A Moral Compass for Ethics in Practice. Critical Social Work 9(1). Available Online: http://www.criticalsocialwork.com/units/socialwork/critical.nsf/98...c9a2852 56d6e 006cff78/3fc6041e5a0302358525744d0006b1a7? OpenDocument.

Wolf-Light, P. (1999). Men, Violence, and Love. In J.. Wild (Ed.). Working with Men for Change (pp.133-152). New York: Routledge.

World Health Organization. (2005). WHO Multi-Country Study on Women's Health and Domestic Violence Against Women: Summary Report of Initial Results on Prevalence, Health Outcomes and Women's Responses. Geneva: World Health Organization. Available Online: http://www.who.int/gender/violence/who multicountry study/summary rep ort.html. 


\section{APPENDIX A: INTERVIEW GUIDE}

1. As you know, this project is about men's participation in community projects to end violence against women. Can you tell me what interested you about this topic enough for you to participate?

2. Why is violence against women a concern for you?

3. Have you, and if yes, in what ways have you, been involved in trying to end violence against women?

4. Is there any other ways that violence against women has touched your life and resulted in your interest in the topic?

5. Do you believe that there is class inequality and/or racial inequality and/or geographical inequality (i.e., Urban - Rural divide) related to violence against women?

6. What do you think are some of the root causes of violence against women?

7. What do you believe are the major challenges those women who are abused face? Can you tell me why you feel that way?

8. Do you think feminism is important or not in ones understanding and analysis of violence against women? Can you elaborate on your beliefs?

9. Do you believe that men have a role in stopping violence against women? Can you tell me why you feel that way?

10. Should men be working with women who are already involved in the struggle to end violence against women? What would this work look like?

11. What do you believe men should do to increase their participation to prevent violence against women?

12. If you are involved with why did you become engaged/involved? 
13. If you are involved with how did you get involved? Can you tell me why you feel that way?

14. Do you believe that your efforts have contributed to change? Can you tell me why you feel that way?

15. How do you believe we can engage other men in the participation to end violence against women? Can you tell me why you feel that way?

16. Do you ever think about whether men should work with women to end violence or whether they should work only with men? Can you tell me why you feel that way?

17. Do you believe that men should work only with men when trying to end violence, or do you feel men should work with women, or we should do both? Can you tell me why you feel that way?

18. Do you believe that we should join or start a men's movement regarding violence against women? Can you tell me why you feel that way?

19. What do you think would be the most effective ways communities could be mobilized to end violence against women? Can you tell me why you feel that way?

20. Do you believe social action is needed too end violence against women? Can you tell me why you feel that way?

21. What do you believe is the most appropriate framework to bring men and women together to end violence against women? Can you tell me why you feel that way?

22. Do you believe there is a "best method" or "best practice" of community development and if so, what is it?

23. Do you believe that social action is needed regarding this issue? If so, what type of social action? If not, why not? 
24. Do you believe there is a "best method" of social action and if so, what is it? Is there any thing else you would like to add about the possibility of men coming together to end VAW?

25. What has been your experience working in your community regarding violence against women? Can you tell me why you feel that way?

26. What do you see the role of government, if any, in the prevention of violence against women? Can you tell me why you feel that way?

27. What are your thoughts on the Minister's Working Group on violence against women? (If familiar with the multi-stakeholder group). Can you tell me why you feel that way?

28. Are there any social policies that you believe needs to be change or challenge in the province of New Brunswick regarding violence against women? Can you tell me why you feel that way?

29. Are there enough programs for women who are experiencing violence against women? What about men, do you believe that there are sufficient programs for men? Do you believe there is a need for programs for men? Can you tell me why you feel that way?

30. Do you believe that men should access funding dollars from the government, private sector, the non-profit sector, and/or the community for their initiatives? Can you tell me why you feel that way? 


\section{APPENDIX B: LETTER OF INFORMATION}

\section{Dear Respondent:}

Are you a man, who is concerned about violence against women in your community? I am Miguel LeBlanc, a Master of Social Work student at Carleton University and conducting a graduate study on men's participation in the prevention of violence against women. As a concerned citizen, you are being invited to participate in this study. Your participation is welcome whether or not you are extensively involved in initiatives to end violence against women; however, some involvement in anti-violence work is required. I would like to find out how you believe we can increase the participation of men in the struggle to end violence against women in New Brunswick. I am also interested in your experience, as well as your thoughts and feelings, on how we as a community can develop community-based initiatives to prevent violence against women. Your participation is very important to the success of my research and it will help me better understand the processes that are needed to increase the participation of men in New Brunswick. Your involvement would include participating in an interview that will last approximately one and a half to two hours. The interview will be conducted at a time convenient to you and we can discuss an appropriate location in your community.

Should you be willing to participate in the interview process, please remember that I will protect your anonymity by using pseudonyms and by removing identifying information when I transcribe the interviews and write my research thesis. This research is of minimal risk to the research participants. Furthermore, your participation is voluntary. You are not required to answer any questions you do not wish to answer. You are free not to participate, and have the right to withdraw from the research at any time. You may also withdraw any of your responses.

The interview will be audio taped and the only people that will listen to the tape will be me, as the researcher. My supervisor will view the transcribed interviews. You will remain anonymous; your name will not appear on these transcripts or tapes. The tapes and transcriptions will be securely locked in storage following the research. Only the researcher will have access to the tapes. I may present the results of this research at conferences, workshops, academic publications or other media sources. The presentation of the research will not identify you, or your work. Your name, as well as any information that could identify you, will be kept strictly anonymous within the research and in any future presentations or publications. 
The data (interview notes, audio tapes, and transcripts) and any identifiable information will be securely locked in a filing cabinet at the researcher's home after the research is completed. Only the researcher will have access to the data. Any data in computer files during the course of the research will be secured with the use of password protected computer files. When the research is complete, the computer files will be printed then deleted from the computer. The printed files will be locked in the filing cabinet with the remainder of the research data. The data may be used in future research with the goal to complete my PhD. However, the data will be destroyed within seven years from the completion of this research project.

At the end of the interview, participants will be given the option of providing the researcher with their contact information so that they can meet with other men to further discuss how men can end violence against women. This group is not part of the study and participants are not required participate in the discussion group as part of their involvement in this study. If any participants decide to participate in the group discussion, their involvement in the group will not be anonymous, since this discussion group is not part of the thesis research.

If you are interested in attaining a copy of a summary of my findings, I shall be pleased to provide it. I will distribute information on the results of the study to any interested participants. Participants who are interested in the results may provide me with a mailing address, or email address at any time throughout the research process. The results will be offered in the form of a summary report.

Should you have any questions and/or concerns about the research or the interview process please feel free to contact me at (Fredericton, New Brunswick) or by email mleblanc@ connect.carleton.ca. If you wish to speak to someone not directly affiliated with my research, you may contact the Chair of Carleton University Research Ethics Committee, Prof. Antonio Gualtieri at - or by email at ethics@ carleton.ca.

I thank you in advance for your participation in my research.

Sincerely,

Miguel LeBlanc, BSW, RSW

Masters of Social Work Candidate

School of Social Work

Carleton University 


\section{CONTACTS}

Miguel LeBlanc, BSW, RSW (Researcher)

Masters of Social Work Candidate

School of Social Work

Carleton University, Ottawa, ON

(Fredericton, NB)

mleblanc@ connect.carleton.ca

Prof. Antonio Gualtieri (Chair)

Carleton University Research Ethics Committee

Carleton University

1125 Colonel By Drive

Ottawa, Ontario

K1S 5B6

ethics@carleton.ca 


\section{APPENDIX C: LETTER OF INFORMED CONSENT}

Contact Person:

Miguel LeBlanc, BSW, RSW

Master of Social Work Candidate

School of Social Work

Carleton University

mleblanc@connect.carleton.ca

(Fredericton, NB)

Prof. Antonio Gualtieri

Chair

Research Ethics

Committee -

Carleton University

Ethics@carleton.ca

I am willing to participate in Miguel LeBlanc's Master of Social Work thesis research project regarding increasing the participation of men in the prevention of violence against women. I have read, or have had read to me, and understand the information provided to me in the letter of Informed Consent. I understand and consent to the following:

I understand that I am consenting to approximately 2-hour interview about men's responses to violence against women.

I understand that my participation is entirely voluntary and I have the right to withdraw my participation at any time during the interview. Furthermore, if I exercise my right to withdraw, I can decide at that point whether or not to give the researcher permission to use the data I provided. I also understand that the interview will take approximately one and a half to two hours to complete.

I understand that this investigation poses minimal risk to participants and that the researcher will tape record the interview process. Further, I understand that the researcher cannot guarantee full confidentiality, since the researcher will be using direct quotes from the participants in the research writing. Therefore, I understand and consent that the researcher will directly quote statements from my interview in the thesis. However, I understand that the researcher will use appropriate methods, such as pseudonyms, removing any identifying information in the transcript and the thesis, which will increase the participant's anonymity. In addition, I understand that if I disclose criminal activities involving the harm (or 
potential harm) of a minor that this information will be disclosed to legal authorities.

I understand that the data (interview notes, audio tapes, and transcripts) and any identifiable information will be securely locked in a filing cabinet at the researcher's home after the research is completed. I understand that only the researcher will have access to the audio data, however, that the researcher's thesis supervisor will view my transcript information. I understand that any data in computer files during the course of the research will be secured with the use of password protected computer files. I understand that when the research is complete, the computer files will be printed then deleted from the computer. I understand that the printed files will be locked in the filing cabinet with the remainder of the research data. I understand and consent that the data may be used in future research with the goal to complete my PhD. However, I understand that the data will be destroyed within seven years from the completion of this research project.

I also understand that at the end of the interview, I will be given the option of providing the researcher with my contact information so that I could meet with other men to further discuss how men can help end violence against women. I understand that it is completely voluntary whether I provide my contact information to the researcher and whether I participate in the group discussion. If I do decide and consent to participate in the group, I understand that it is not part of this research project; rather, it is an opportunity to discuss with other research participants their thoughts and ideas as a group, regarding the issues of violence against women in New Brunswick, and as such, my anonymity and confidentiality are not protected.

I understand that the main purpose of this research is to fulfill the partial requirements for the researcher's Master of Social Work degree and therefore, the results of the research will be presented to the School of Social Work at Carleton University in thesis format. In addition, I understand that the researcher may present the results of this research at conferences, workshops, academic publications or other media sources. I also understand that I can request a copy of the summary of the research from the researcher.

In the event that I should have any questions, concerns, or complaints about the project I can contact the chair of Carleton University Ethics Committee, Prof. Antonio Gualtieri at

Participant's Name

Participant's Signature 
Researcher's Signature

Date 